\title{
HUMAN BIOAVAILABILITY OF VITAMINS
}

Members of EC Flair Concerted Action No. 10: 'Measurement of micronutrient absorption and status' $\dagger$

Compiled by: C. J. BATES ${ }^{1}$ AND H. HESEKER

${ }^{1}$ MRC Dunn Nutrition Unit, Milton Road, Cambridge CB4 1XJ, UK

\section{CONTENTS}

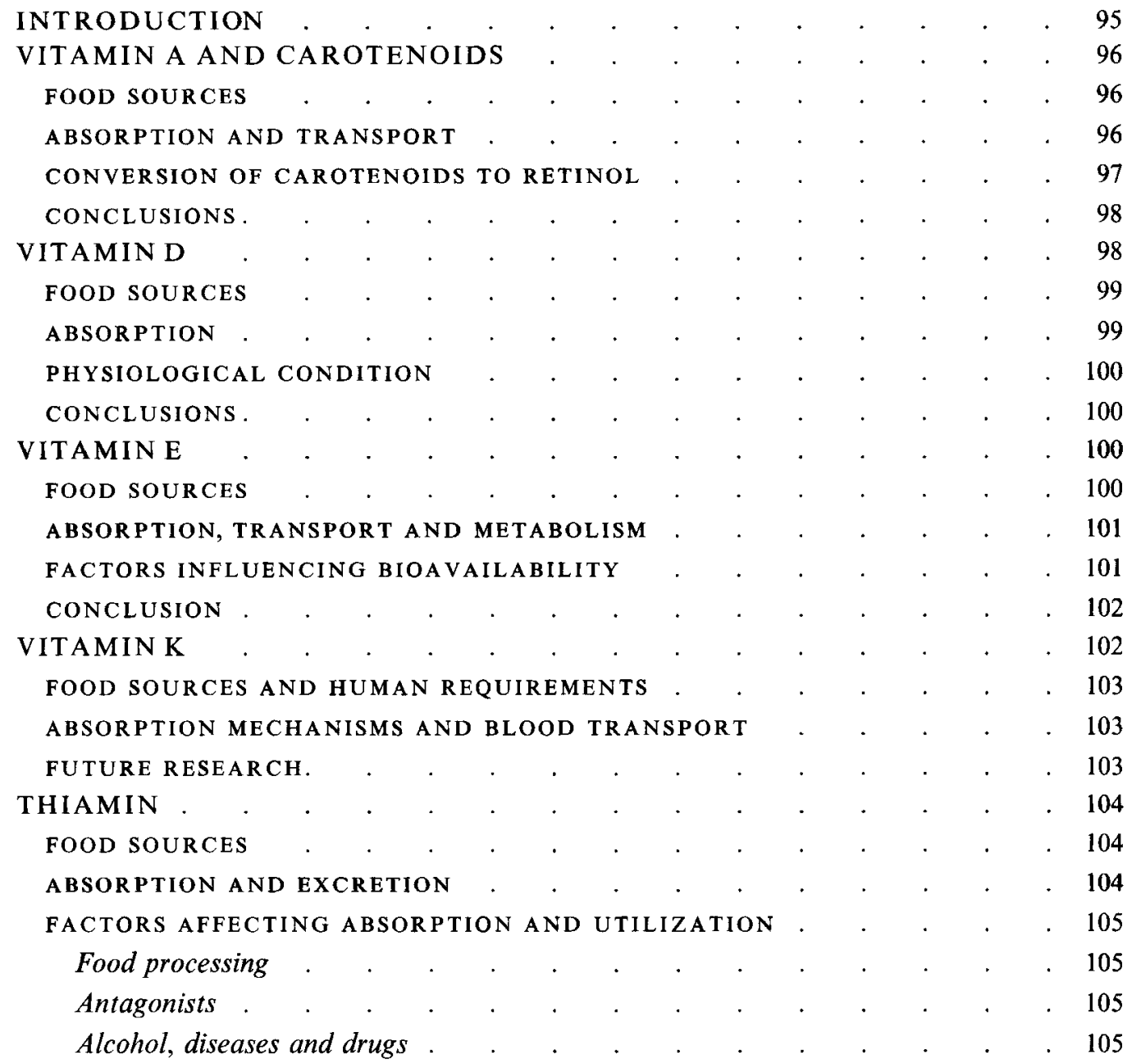

† Contributors: H. van den Berg, Zeist, Netherlands (introduction (van den Berg, 1993) and vitamin D); C. J. Bates, Cambridge, UK (vitamin K, riboflavin and vitamin C); R. Bitsch, Jena, Germany (vitamin $B_{6}$ ); P. Finglas, Norwich, UK (thiamin); H. Heseker and J. Zempleni, Giessen, Germany (niacin); M. Jagerstad and K. Wigerty, Lund, Sweden (folate); G. Maiani, M. Serafini and A. Ferro-Luzzi, Rome, Italy (biotin and pantothenate); K. Pietrzik and J. Dierkes, Bonn, Germany (vitamin B $_{12}$ ); A. Sheehy, Cork, Eire (vitamin E); C. E. West and T. van Vliet, Wageningen/Zeist, Netherlands (vitamin A and carotenoids). 
Smoking and age . . . . . . . . . . . . . . . 105

Other nutrient interactions . . . . . . . . . . . . . . . . . . . . 106

CONCLUSIONS. . . . . . . . . . . . . . . . . . . . 106

RIBOFLAVIN . . . . . . . . . . . . . . . . . . 106

FOOD SOURCES .

RELEASE AND ABSORPTION . . . . . . . . . . . . . . . . 106

EXCRETION . . . . . . . . . . . . . . . . . . . . . 107

ANTAGONISTS AND HOMEOSTATIC INFLUENCES . . . . . . . . 107

CONCLUSION . . . . . . . . . . . . . . . . . . . . . 107

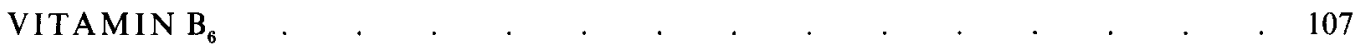

FOOD PROCESSING; BOUND B 6 .

INTERACTIONS WITH NUTRIENTS AND DRUGS. . . . . . . . 109

CONCLUSION . . . . . . . . . . . . . . . . . 109

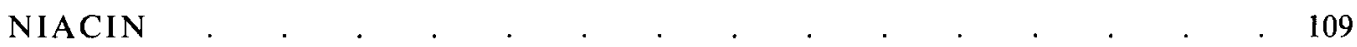

FOOD SOURCES .

RELEASE AND ABSORPTION . . . . . . . . . . . . . . . 110

EXCRETION . . . . . . . . . . . . . . . . . . . . 110

SYNTHESIS FROM TRYPTOPHAN . . . . . . . . . . . . . 110

METABOLISM AND TRANSPORT BETWEEN TISSUES . . . . . . . . 110

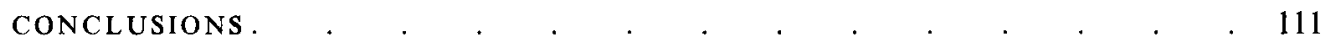

FOLATE . . . . . . . . . . . . . . . . . . . . 111

ABSORPTION OF SYNTHETIC MONO- AND POLY-GLUTAMYL FOLATES . . 111

AVAILABILITY OF FOOD FOLATES . . . . . . . . . . . . 112

MILK FOLATE BINDING PROTEIN. . . . . . . . . . . . . . 112

DIETARY FIBRE AND MATRIX EFFECTS . . . . . . . . . 112

EXCRETION . . . . . . . . . . . . . . . . . . . . 113

CONCLUSIONS AND FUTURE RESEARCH PRIORITIES . . . . . . . 113

$\operatorname{VITAMIN~} B_{12}$.

VITAMIN B 12 IN FOOD . . . . . . . . . . . . . . . . 113

ABSORPTION . . . . . . . . . . . . . . . . . . . 114

RETENTION . . . . . . . . . . . . . . . . . . . . . . 114

CONCLUSION . . . . . . . . . . . . . . . . . . . . . 114

BIOTIN .

ABSORPTION AND EXCRETION . . . . . . . . . . . . . 115

DIETARY SOURCES . . . . . . . . . . . . . . . . . . . 115

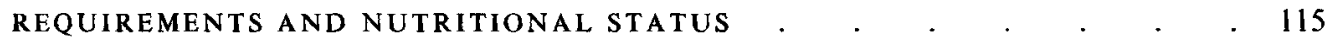

CONCLUSION . . . . . . . . . . . . . . . . . . . 116

PANTOTHENIC ACID . . . . . . . . . . . . . . . . . . . . . 116

RELEASE AND ABSORPTION . . . . . . . . . . . . . . . . . . 116

EXCRETION . . . . . . . . . . . . . . . . . . 116

NUTRITIONAL STATUS AND INDUCED DEFICIENCY . . . . . . . 116 


\begin{tabular}{l}
$\begin{array}{l}\text { CONCLUSION } \\
\text { VITAMIN C }\end{array} \quad$. \\
\hline
\end{tabular}

\section{INTRODUCTION}

Although vitamins are usually considered to be well absorbed and readily available compared with mineral nutrients, there are situations where bioavailability is limited. Absorption processes are complex, and not completely understood, and interactions with food and physiological processes are critical.

The percentage absorption of individual vitamins from food in the human intestine varies between 20 and $98 \%$. Active transport in the duodenum and ileum has been shown for retinol and the water-soluble vitamins except $B_{6}$ and pantothenate. This is characterized as saturable, sodium dependent, high affinity and low capacity, and is therefore most important at low intraluminal concentrations (Matthews, 1974; Rose, 1988; Bowman et al. 1989). It was missed in some of the earlier studies of transport mechanisms which had to rely on relatively insensitive detection methods. At high concentrations, passive diffusion generally predominates.

Water-soluble vitamins may occur in protein bound forms which require release by proteinase or phosphatase action before absorption. Stomach acidity may be critical, and pathology may influence absorption.

Food intake usually enhances vitamin absorption by stimulating enzyme and bile acid secretion, and by increasing transit time (Jusko \& Levy, 1975). In contrast, some foods contain inhibitors of vitamin utilization, which reduce solubility or release. Proteinase inhibitors in some raw fruits and vegetables can affect vitamin absorption, as can substances which reduce bile acid reabsorption (Kern et al. 1978).

Food processing may have either beneficial or adverse effects. Beneficial effects include the removal of antivitamin factors, or interconversions which enhance availability. Changes in fat content, its saturation level, and the use of fat substitutes may have profound effects on fat-soluble vitamin availability.

Measurement of vitamin bioavailability is a complex problem. Simple pharmacokinetic parameters, such as area under or maximum height of the curve of plasma concentration following a test dose, may not be suitable, if pre-existing stores and postabsorption events interfere, as they often do. Animal based studies using growth rates or other dose-effect relationships, urinary excretion or balance studies (for fat-soluble vitamins) can yield very useful information, but they may not be ideal to investigate bioavailability in humans, because of interspecies differences. The use of stable isotope labelled vitamins in man seems promising, but is still at an early stage of development.

Vitamin absorption does not appear to be controlled by the body pool size, as is the case for some metal ions, and only vitamins $A$ and $B_{12}$ are stored (in the liver) in amounts greatly in excess of the immediate functional requirement. Excess amounts of water-soluble vitamins are generally removed by urinary excretion; those of some fat-soluble vitamins by 
biliary excretion. Turnover rates (metabolic degradation) largely determine minimum daily requirements; these have not yet been determined precisely for humans. Adaptation to varying intake levels is poorly understood and deserves further study. The effects of age and sex are poorly characterized: nutrient density requirements may be different for old people than for children or young adults; pregnancy, lactation and preterm birth clearly have major effects on requirements and, possibly, on availability. Metabolic diseases and drug use may likewise affect vitamin availability (van den Berg, 1991).

In conclusion, the bioavailability of vitamins owes its complexity to the fact that enhancers or inhibitors in foods, the different chemical form of vitamers, and the physiological state of the subject, all affect availability. Quantitative data, especially for vitamins in foods and diets, are scarce and, as a result, requirement estimates are imprecise. New standardized methods of estimation over physiologically relevant intake ranges are needed. Bioavailability needs to be included in the evaluation of commercial food products and in their design. In view of current health concerns that focus on the antioxidant vitamins for their relevance to degenerative diseases, and on the special micronutrient requirements of pregnant and lactating women, the elderly, adolescents, dieters, preterm infants, and other high risk groups, this challenge assumes considerable practical significance. Please refer to van den Berg (1993) for a more detailed discussion.

Each vitamin will now be considered in more detail.

\section{VITAMIN A AND CAROTENOIDS}

Vitamin A is obtained either preformed, or from provitamin A carotenoids. There are two forms: retinol (vitamin $A_{1}$ ), the most common, and 3-dehydroretinol (vitamin $A_{2}$ ) with about half the activity. Most dietary vitamin A occurs as esters, readily hydrolysed in the gut. Other active compounds are retinal (convertible to retinol), and retinoic acid and its $\beta$-glucuronides which replace retinol in functions such as growth and differentiation, but not vision. Retinyl esters are less polar and retinoic acid and glucuronides more polar than vitamin A. Hydroxycarotenoids, e.g. lutein, are more polar than carotenoids such as $\beta$-carotene (Craft \& Soares, 1992). Carotenoids may protect against cancer and may modify the immune response, independently of retinol. Disease prevalence seems frequently related to carotenoid intake but not to serum retinol levels. Antioxidant and other functions of carotenoids have been considered (Burton, 1989). Retinol, retinal and retinoic acid are toxic in excess (Bendich \& Langseth, 1989); carotenoids are generally regarded as nontoxic.

\section{FOOD SOURCES}

Rich sources of retinol are animal products such as milk, butter, cheese, egg yolk, liver and marine fishes; dehydroretinol is common in freshwater fishes. Traces of retinal, retinoic acid and the glycosides of retinol and retinoic acid also occur in foods. Carotenoids occur in dark green leafy vegetables and yellow and orange coloured fruits and vegetables, but less in animal products. In meat, fish and oils from animals and fish, $10 \%$ of the vitamin activity occurs as carotenoids, while in poultry, eggs and milk $30 \%$ occurs as carotenoids (Wu Leung et al. 1968).

\section{ABSORPTION AND TRANSPORT}

Retinyl esters are hydrolysed in the intestinal lumen by the same pancreatic enzyme which hydrolyses cholesteryl esters. Retinol is then absorbed into enterocytes by facilitated diffusion at physiological concentrations $(<150 \mathrm{nM})$ involving a cellular retinol binding 
protein (Said et al. 1989), or by passive diffusion at pharmacological levels. In enterocytes, retinol is esterified by microsomal enzymes, lecithin:retinol acyltransferase and acyl-CoA:retinol acyltransferase; the latter mainly at high retinol loads. Retinyl esters enter chylomicrons and are transported via the thoracic duct to the blood. Goodman et al. (1966) showed that one fifth of orally administered radioactive retinol was recovered in thoracic lymph, and Sauberlich et al. (1974) showed that half of an oral load is recovered in the liver.

Water-soluble retinoids such as retinoic acid and glycosides of retinol and retinoic acid travel from the intestine via the portal vein to the liver, where retinol and retinoic acid are glycosylated and then excreted into bile (Barua et al. 1989).

Carotenoids are absorbed from the small intestine into enterocytes by passive diffusion (Hollander \& Ruble, 1978) and thence via chylomicrons to lymph. Less than one sixth of $\beta$-carotene is absorbed intact in humans (Goodman et al. 1966). Balance studies indicate that $50-75 \%$ of $\beta$-carotene may be utilized (Lala \& Reddy, 1970) but breakdown may also occur. The initial increase in $\beta$-carotene level on feeding is in the chylomicrons and VLDL fraction (Johnson \& Russell, 1992). The kinetics of the serum response to oral $\beta$-carotene is not simply dependent on dose (Henderson et al. 1989); indeed, when large doses are fed the serum level increases exponentially (Prince et al. 1991).

Study of the absorption of carotenoids other than $\beta$-carotene has recently been facilitated by high pressure liquid chromatography. Lutein and canthaxanthin are accumulated in the eye, while $\alpha$ - and $\beta$-carotene, lycopene, zeaxanthin and cryptoxanthin accumulate in various tissues (Kaplan et al. 1990; Stahl et al. 1992). Micozzi et al. (1992) found that feeding $\beta$-carotene reduced the concentration of lutein in serum while Henderson et al. (1989) found no effect of $\beta$-carotene on serum level of $\alpha$-carotene, cryptoxanthin, lycopene and lutein.

Jensen et al. (1987) concluded that all-trans $\beta$-carotene is absorbed more readily in man that the 9-cis form because from mixtures the proportion of 9-cis in serum was less than one sixth of that in the mixture fed. However, Stahl et al. (1992) showed that the proportions of 9-, 13- and 15-cis isomers were much higher in liver and other tissues than in serum.

\section{CONVERSION OF CAROTENOIDS TO RETINOL}

Provitamin A carotenoids are converted to retinol primarily in the enterocytes, but also in tissues such as liver. The first FAO/WHO (1967) expert group on vitamin A requirements proposed that $6 \mu \mathrm{g} \beta$-carotene is equivalent to $1 \mu \mathrm{g}$ retinol. The second FAO/WHO (1988) expert group proposed that the amount of $\beta$-carotene equivalent to $1 \mu \mathrm{g}$ retinol is 4,6 and $10 \mu \mathrm{g}$ for intakes per meal of $<1000,1000-4000$ and $>4000 \mu \mathrm{g} \beta$-carotene respectively.

For vitamin A activity a carotenoid needs at least the unaltered $\beta$-ionone ring structure with an attached polyene side chain containing 11 carbons. Simpson \& Chichester (1981) have suggested on the basis of structure alone that $50-60$ carotenoids and apocarotenoids could have vitamin A activity.

The enzyme responsible for the formation of retinol from $\beta$-carotene in intestinal mucosa, carotene $15,15^{\prime}$-dioxygenase*, has been only partly purified (Goodman \& Huang, 1965; Olson \& Hayaishi, 1965). It is not known whether just one enzyme exists, or whether the cleavage of $\beta$-carotene is always central, yielding two molecules of retinal. In studies by

* (EC 1.13.11.21). 
Goodman \& Huang (1965) and Olson \& Hayaishi (1965) in rats, central cleavage predominated. In in vitro studies, Gronowska-Senger \& Wolf (1970) found retinal to be the sole product of cleavage, while Wang et al. (1991) identified $\beta$-apo-12'-carotenal $(80 \%)$ and $\beta$-apo-10'-carotenal $(11 \%)$ as the main products and retinal as only $5 \%$. Few studies have been carried out in vivo in humans. Goodman et al. (1966) showed that of the radioactive $\beta$-carotene recovered in the lymph, most of that metabolized was retinyl esters, retinol and retinal. In a study using ${ }^{13} \mathrm{C}$-labelled $\beta$-carotene in humans, Parker et al. (1992) recovered most of the label in retinyl esters. Such evidence suggests that $\beta$-carotene cleavage is central. Feeding $\beta$-carotene-rich foods increases serum retinol levels only when these are initially low (Lala \& Reddy, 1970). No studies have been carried out in humans on the effect of vitamin A status on dioxygenase activity although studies in rats (Villard \& Bates, 1986) as well as in hamsters (Van Vliet et al. 1992) have shown that diets low in vitamin A may increase dioxygenase activity. Low protein diets reduced dioxygenase activity in rats (Gronowska-Senger \& Wolf, 1970). Failure to split $\beta$-carotene in man is rare but can lead to metabolic carotenaemia at low intakes of carotenoids (Monk, 1982) or to vitamin A deficiency if retinol intake is low (McLaren \& Zekian, 1971).

Pure $\beta$-carotene is absorbed more readily than that in foods (Hume \& Krebs, 1949). Thus the plasma response to pure $\beta$-carotene was about five times that of a similar amount in carrots (Brown et al. 1989; Micozzi et al. 1992). Absorption of carotenoids is markedly reduced when the intake of fat is low, and bile acids are necessary to prevent inhibition of the intraluminal phase of digestion ('maldigestion'). $\beta$-Carotene absorption in humans is reduced by pectin (Rock \& Swendseid, 1992). Higher serum levels of $\beta$-carotene but not lycopene were found in women than in men (Kaplan et al. 1990). Carotene absorption is not affected by age (Maiani et al. 1989). Defects in absorption ('malabsorption') are seen in non-tropical sprue (Evans \& Wollaeger, 1966) and cystic fibrosis (James et al. 1992). Intestinal parasites, however, do not interfere with carotene absorption. Absorption of carotenes in underweight children appears normal (Lala \& Reddy, 1970). Acute respiratory infections, however, reduce absorption as measured by serum carotenoid levels (Heymann, 1936; Lala \& Reddy, 1970).

\section{CONCLUSIONS}

The availability of preformed vitamin $\mathrm{A}$ is much greater than that of precursor carotenoids. There are important unsolved questions regarding the distribution of vitamin $A$, its delivery, turnover and toxicity at large intakes.

Further studies are also needed on the carotenoid content of foods, from different food matrices, with different levels of fat in the diet and in the presence of various parasites, on the extent of carotenoid absorption especially from different food matrices, on the extent of conversion of carotenoids to retinol and on the biological significance of the carotenoids.

\section{VIT A MIN D}

Vitamin D is the generic name for a group of closely related secosteroids exhibiting qualitatively the biological activity of cholecalciferol (vitamin $\mathrm{D}_{3}$ ). The international unit is equivalent to $1 / 40 \mu \mathrm{g}$ cholecalciferol. The fat-soluble vitamin $\mathrm{D}$ is only an essential nutrient under conditions of limited sun exposure of the skin, as the vitamin can be made endogenously in the skin epidermis from 7-dehydrocholesterol by action of ultraviolet light (DeLuca, 1988). 25-Hydroxyvitamin D (25-OHD), formed in the liver, and 1,25dihydroxyvitamin $\mathrm{D}(1,25-\mathrm{DHD})$, produced by the kidneys, are the most important 
metabolites. Synthetic ergocalciferol (vitamin $D_{2}$ ) is assumed to have the same biological activity in man as the 'natural' cholecalciferol (vitamin $D_{3}$ ) from animal origin. Quantitative data on the human body pool are lacking. Adipose tissue and voluntary muscle are the principal storage sites of (non-hydroxylated) vitamin D in man (Mawer $e t$ al. 1972). The factors controlling the release of vitamin $D$ from these stores are largely unknown but are most likely related to lipolysis and muscle protein breakdown, rather than vitamin D status per se. Liver and other tissues also contain some 25-OHD. In high dosages vitamin D can be toxic, especially in children (see Hathcock, 1985). Vitamin D toxicity seems attributable to high levels of 1,25-DHD (Vieth, 1990).

\section{FOOD SOURCES}

Only a few foods contain significant amounts of vitamin D, e.g. fatty fish and fish oils. Meat, especially liver, and dairy products contain up to about 100 international units $/ 100 \mathrm{~g}$. Human and bovine milk also contain 25-OHD (Hollis et al. 1981 a), which has a higher biological activity than the non-hydroxylated vitamin D (Tanaka et al. 1973). The watersoluble vitamin D activity in milk is explained by the presence of protein bound 25-OHD (Hollis et al. 1981 b). Meat products may also contain low amounts of 25-OHD which may contribute up to $50 \%$ of the vitamin D activity, and in many countries margarines, and sometimes milk products, are fortified with vitamin $\mathrm{D}$ (vitamin $\mathrm{D}_{2}$ or $\mathrm{D}_{3}$ ). Some plants have been reported to contain compounds with vitamin D activity (e.g. 1,25-DHDglycoside in Solanaceae; Boland, 1986). Vitamin D is an acid- and heat-labile compound, but is generally stable during storage and processing in foods.

\section{ABSORPTION}

Vitamin $\mathrm{D}$ is, with the other fat-soluble vitamins, absorbed by emulsification into mixed micelles, uptake in the enterocyte, followed by incorporation in the chylomicrons and transport into the circulation via the lymphatic pathway (Hollander, 1981). Vitamin D esters, if present, are hydrolysed during solubilization in the mixed micelles. Vitamin D is efficiently absorbed in the proximal small intestine in the presence of fat (dependent on bile acid secretion). Long chain fatty acids facilitate the absorption of vitamin D (Holmberg et al. 1990).

The more polar hydroxylated metabolites (25-OHD) are at least partly absorbed via the portal venous system (Maislos et al. 1981). 25-OHD is more rapidly and efficiently absorbed than unhydroxylated vitamin $D$ and is less dependent on bile salts (Sitrin \& Bengoa, 1987). For both vitamin $\mathrm{D}$ and 25-OHD a clear dose-response relation between intake and serum 25-OHD content has been established (Whyte et al. 1979). A single large oral dose of vitamin D was found to give the same serum peak 25-OHD level as the same amount given in small doses over a longer period (Stamp, 1975).

Although bile is the main route for vitamin $\mathrm{D}$ excretion, the significance of a conservative enterohepatic circulation is still controversial and probably only functionally significant in conditions of a marginal vitamin D status (Gascon-Barré, 1986). A high fibre diet has been reported to lead to enhanced elimination of vitamin D (Batchelor \& Compston, 1983). This may at least partly explain the low vitamin D status observed in vegetarians and macrobiotics (Dagnelie et al. 1990). Iron deficiency may result in impaired vitamin D absorption (Heldenberg et al. 1992).

Vitamin D bioavailability is mainly measured as the increase in 25-OHD after an oral load of vitamin D. Most of the available data on vitamin D availability relate to relative 
rather than absolute absorption. In animal experiments overall net absorption rates between 66 and $75 \%$ have been reported (Weber, 1981). For man, an average absorption of $50-80 \%$ from a mixed diet has been estimated (Lawson, 1980).

\section{PHYSIOLOGICAL CONDITION}

There is no evidence that vitamin $\mathrm{D}$ absorption, contrary to its postabsorptive utilization, is affected by vitamin D status (Stamp, 1975; Fraser, 1983). In conditions of primary or secondary hyperparathyroidism, increased metabolic inactivation of vitamin $\mathrm{D}$ has been reported (Clements et al. 1987). Although ageing may compromise vitamin D metabolism, especially at the level of 1,25-DHD production and receptor responsiveness, it does not seem to affect vitamin D absorption (Horst et al. 1990).

\section{CONCLUSIONS}

A large part of the vitamin $\mathrm{D}$ requirement is met by skin synthesis rather than by dietary ingestion. This is especially true under conditions with ample solar exposure. However, people living at latitudes above $50^{\circ}$ need dietary sources, especially during the winter period, to maintain adequate vitamin D status (Webb et al. 1988). Also, groups with a limited capacity for endogenous vitamin D synthesis, such as people with heavily pigmented skins, or living at higher altitudes, or the elderly (with age related changes in skin thickness) are more dependent on dietary sources or supplements (Need et al. 1993). Only a limited number of foods contains vitamin D, sometimes present as $25-O H D$. Vitamin D is normally efficiently absorbed in the proximal small intestine. For absorption, the presence of fat and normal gastrointestinal function (fat digestion) are prerequisites. Absorption of 25-OHD is more efficient than that of the non-hydroxylated form and less dependent on bile acid secretion, as the more polar 25-OHD is preferentially absorbed via the portal system instead of the lymph (in chylomicrons).

\section{VITAMIN E}

Vitamin E activity in foods is derived from two groups of fat-soluble compounds of plant origin called tocopherols and tocotrienols (Kasparek, 1980). $\alpha$-Tocopherol is a derivative of 2-methyl-6-chromanol to which a saturated 16-carbon isoprenoid chain is attached at $\mathrm{C}(2)$, and which is methylated at $\mathrm{C}(5), \mathrm{C}(7)$ and $\mathrm{C}(8)$. The other forms $(\beta-, \gamma-, \delta-)$ differ in the number and position of the methyl groups on the chromanol ring. Tocotrienols differ from tocopherols in that the side chain is unsaturated at $\mathrm{C}\left(3^{\prime}\right), \mathrm{C}\left(7^{\prime}\right)$ and $\mathrm{C}\left(11^{\prime}\right)$.

The biological activity of tocopherols is influenced by the configuration of both the chromanol ring and the side chain (Drevon, 1991). Because the most active form, RRR- $\alpha$ tocopherol, is neither easily available nor stable, the International Unit is based on synthetic (all-rac) $\alpha$-tocopheryl acetate, an equimolar mixture of all eight possible stereoisomers.

\section{FOOD SOURCES}

$\alpha$-Tocopherol in the diet occurs mainly in the unesterified form. Its distribution in plants is influenced by species, variety, and stage of maturity as well as by harvesting, processing and storage procedures (Bauernfeind, 1980). The richest dietary sources of $\alpha$-tocopherol are vegetable oils. Cereals are good sources, while supplies in fruits and vegetables are generally moderate to poor. Animal products are usually low in $\alpha$-tocopherol, although the 
concentration can be increased by dietary supplementation. Some oils and cereals provide appreciable amounts of other tocopherols and tocotrienols.

\section{ABSORPTION, TRANSPORT AND METABOLISM}

$\alpha$-Tocopherol is absorbed unchanged from the intestinal lumen, whereas tocopheryl esters are first hydrolysed by pancreatic esterase (Bjørneboe et al. 1990). Pancreatic juice and bile are essential for this process. The greatest capacity for absorption appears to be in the region between the upper and middle thirds of the small intestine (Gallo-Torres, 1980).

It is generally considered that the absorption of $\alpha$-tocopherol and its esters is incomplete. However, precise absorption efficiencies are uncertain. Absorption of a single bolus of $\alpha$ tocopherol by rats was calculated to be approximately $40 \%$ (Bjørneboe et al. 1986), while $65 \%$ absorption was observed when $\alpha$-tocopheryl acetate was administered to rats as a slow, continuous infusion (Traber et al. 1986). In human studies, estimates of 24-h absorption efficiencies for $\alpha$-tocopherol and $\alpha$-tocopheryl acetate range from 21 to $86 \%$ (Gallo-Torres, 1980). Interpretation of these results is complicated by the limited sample numbers and the variety of experimental approaches used by different authors. Data are lacking on the efficiency of vitamin $\mathrm{E}$ absorption from foods.

There are no major differences in the absorption of $\alpha$ - and $\gamma$-tocopherol (Traber et al. 1986) but the latter is preferentially excreted in bile (Traber \& Kayden, 1989), which accounts for its lower concentration in plasma despite its widespread distribution in the diet. The other tocopherols ( $\beta$ - and $\delta$-) are poorly absorbed (Gallo-Torres, 1980).

$\alpha$-Tocopherol enters the enterocyte by passive diffusion and is secreted into chylomicrons. Hydrolysis of chylomicrons in the circulation by lipoprotein lipase forms chylomicron remnants which are taken up by the liver, from which $\alpha$-tocopherol is secreted in VLDL (Traber et al. 1988). Metabolism of VLDL results in the simultaneous delivery of $\alpha$-tocopherol into LDL and HDL. The uptake of $\alpha$-tocopherol by peripheral tissues may occur during the catabolism of chylomicrons and VLDL by lipoprotein lipase, via the LDL receptor or by uptake that is not dependent upon receptors (Drevon, 1991). In rats, uptake is most rapid in lung, liver, small intestine, plasma, kidney and red cells and slowest in brain, testes, adipose tissue and spinal cord (Ingold et al. 1987). The major stores of $\alpha$-tocopherol in the body are adipose tissue, liver and muscle (Drevon, 1991). However, mobilization of adipose tissue $\alpha$-tocopherol in response to dietary vitamin E deficiency is very slow (Bjørneboe et al. 1990).

Apart from oxidation and reduction, the metabolism of $\alpha$-tocopherol is limited (Drevon, 1991). However, when large doses are ingested, a considerable amount of $\alpha$-tocopherol is secreted in bile, which may account for the relative safety of vitamin $\mathbf{E}$ compared to vitamins A and D (Traber \& Kayden, 1989). The principal route of elimination is via the faeces, arising from incomplete absorption, secretion from mucosal cells, desquamation and biliary excretion. The extent of faecal excretion may vary from 10 to $75 \%$ of the administered dose while urinary excretion represents about $1 \%$ of the dose (Gallo-Torres, 1980).

\section{FACTORS INFLUENCING BIOAVAILABILITY}

Vitamin $\mathrm{E}$ bioavailability is influenced by a variety of luminal and physiological factors. In animal bioassays, the choice of vehicle used to deliver the test compound is an important variable (Burton et al. 1988). Solubilization of the vitamin in medium chain compared to long chain tryglycerides enhances hydrolysis and absorption, possibly by influencing the formation of micelles (Gallo-Torres, 1980; Fukui et al. 1989). Administration in an oil solution, a mixed diet or in capsule form influences whether oxidation of the vitamin occurs 
in the intestinal chyme, while high intakes of polyunsaturated fatty acids may increase the oxidation of $\alpha$-tocopherol in vivo (Bjørneboe et al. 1990).

Studies in rats have indicated that the bioavailability of vitamin $E$ increases with age (Hollander \& Dadufalza, 1989) but is reduced by high intakes of pectin (Schaus et al. 1985), wheat bran (Omaye \& Chow, 1984; Kahlon et al. 1986) and alcohol (Bjørneboe et al. 1990). One group (Verdon \& Blumberg, 1988) reported that the activity of hepatic $\alpha$-tocopherol binding protein increases during vitamin $\mathrm{E}$ deficiency, suggesting that bioavailability is higher when vitamin $\mathrm{E}$ status is low. However, other workers (Burton et al. 1988) observed that the overall absorption and transport of RRR- $\alpha$-tocopherol and RRR- $\alpha$-tocopheryl acetate was similar in vitamin $E$ replete and deficient rats.

The development of stable isotope methods represents an important advance in the study of vitamin E bioavailability. Studies using stable isotopes have shown that RRR-and allrac $\alpha$-tocopheryl acetate are absorbed equally well in both rats and humans under normal conditions (Burton et al. 1988). However, long term feeding of deuterium substituted RRRand SRR- $\alpha$-tocopheryl acetate to rats indicated that some tissues, especially brain, have a marked preference for RRR- $\alpha$-tocopherol (Ingold et al. 1987). A similar, though less pronounced, preference is evident in human red blood cells and plasma (Traber et al. 1990). Discrimination may be due partly to the preferential secretion of RRR- $\alpha$-tocopherol into VLDL. While these experiments confirm the greater bioavailability of the natural stereoisomer, they also suggest that bioassay duration and the tissues in which the symptoms of deficiency and cure are observed, can influence the biopotency estimate (Ingold et al. 1987, 1990). Consequently, the results of animal bioassays must be interpreted with caution. Extension of stable isotope studies in humans should provide more reliable data regarding the uptake and retention of compounds with vitamin $E$ activity.

\section{CONCLUSION}

Vitamin E consists of eight naturally occurring fat-soluble compounds of which $\alpha$-tocopherol has the highest biological activity. $\alpha$-Tocopherol is absorbed unchanged from the intestine whereas tocopheryl esters are hydrolysed before absorption. The absorption process is incomplete but precise efficiencies remain to be established. $\alpha$-Tocopherol is absorbed via the lymphatic pathway and transported in association with chylomicrons. At normal intakes, $\alpha$-tocopherol is exported from the liver to the peripheral tissues in VLDL but pharmacological doses lead to some biliary losses. The major stores are adipose tissue, liver and muscle. Some tissues show a strong preference for natural (RRR-) rather than synthetic (all-rac) $\alpha$-tocopherol. There is clearly a need for further research on vitamin $\mathrm{E}$ bioavailability, particularly from important food sources, because of its possible role in chronic disease prevention.

\section{VITAMIN K}

Vitamin $\mathrm{K}$ exists in two major forms: phylloquinone or vitamin $\mathrm{K}_{1}$ from plants, and bacterial forms, the menaquinones which have variable side chain lengths, known collectively as vitamin $\mathrm{K}_{2}$. A third water-soluble substance with vitamin $\mathrm{K}$ activity, which is purely synthetic, is menadione which lacks the hydrocarbon side chain. During the carboxylation* of glutamic acid residues in the proteins involved in blood clotting (Stenflo et al. 1974), in bone formation (Suttie, 1984), and other oxidation states, vitamin K epoxide and hydroquinone are formed transiently. More is known about the biological activity of

* involving vitamin $\mathrm{K}$. 
diet derived phylloquinone than of gut flora menaquinones. Phylloquinone is considered non-toxic in pharmacological amounts; menadione is potentially toxic and should be used with caution.

\section{FOOD SOURCES AND HUMAN REQUIREMENTS}

Rich sources of phylloquinone include leafy vegetables (e.g. broccoli, spinach, lettuce, Brussels sprouts) and liver (Suttie, 1984); typical concentrations range between ten and a few hundred micrograms per $100 \mathrm{~g}$. Human requirements are $0.4-1 \mu \mathrm{g} / \mathrm{kg}$ body weight (Olson, 1987; Suttie et al. 1988). Absorption of menaquinones from the colon is limited, and their biological activity is uncertain (Shearer et al. 1974; Shearer, 1990).

Biochemical changes, including those of protein carboxylation, have been observed in adult human subjects receiving a diet low in vitamin K (Ferland et al. 1993). Nevertheless, a severe functional deficiency of vitamin $\mathrm{K}$ in adult humans is rarely achieved by diet alone, but requires antibiotics also, to interrupt the supply from the gut flora (Allison et al. 1987).

Young infants, especially if breast fed, are potentially at risk of developing functional vitamin $\mathrm{K}$ deficiency, particularly with respect to the blood clotting cascade (Shearer $e t$ al. 1982; Lane \& Hathaway, 1985; Greer et al. 1988; Yang et al. 1989; Matsuda et al. 1991; Guillaumont et al. 1993; Schubiger et al. 1993; von Kries et al. 1993). There is evidence of considerable variation in the absorptive capacity of individual infants (Shinzawa $e t$ al. 1989).

\section{ABSORPTION MECHANISMS AND BLOOD TRANSPORT}

Phylloquinone is mainly absorbed in the proximal ileum, by an energy dependent pathway, into the lymphatic circulation (Blomstrand \& Forsgren, 1968). Studies in rat gut segments indicated that phylloquinone was taken up most readily in the proximal ileum (Hollander, 1973) but that menaquinones of bacterial origin could be absorbed by the mammalian colon, at a rate sufficient to prevent a functional deficiency (Hollander et al. 1977). Since oestrogens can affect vitamin $\mathrm{K}$ absorption (Jolly et al. 1977), it is likely that the requirements differ somewhat between males and females.

Bjornsson et al. $(1979,1980)$ infused $\left[{ }^{3} \mathrm{H}\right]$ phylloquinone into human subjects and made calculations of the half life and body pool size, the latter being remarkably small.* Shearer et al. (1974) obtained similar values: after an oral dose of $1 \mathrm{mg}$ labelled phylloquinone a peak plasma level was observed after about $2 \mathrm{~h}$, declining exponentially to baseline values after $48-72 \mathrm{~h}$ (Shearer et al. 1970). Vitamin $\mathrm{K}$ is probably transferred from the chylomicron remnants to the liver, is then incorporated into very low density lipoproteins and transported to other tissues via low density lipoproteins (Sadowski et al. 1988). No specific carrier protein for vitamin $\mathrm{K}$ has been identified, but apolipoprotein $\mathrm{E}$ seems especially important in plasma vitamin $\mathrm{K}$ transport, in relation to chylomicron remnant clearance (Saupe et al. 1994). Both phylloquinone and high molecular weight menaquinones from bacteria are found in the liver (Rietz et al. 1970).

\section{FUTURE RESEARCH}

Vitamin $\mathrm{K}$ research has, in the past, been hampered by the difficulty of measuring the very low concentrations that occur in blood and tissues. Developments in chromatographic and detection procedures are now beginning to overcome this problem, and the use of stable

$$
\text { * (50-100 } \mu \mathrm{g})
$$


isotopes should also facilitate future studies of bioavailability and disposition of vitamin $\mathrm{K}$ in humans. Clearly there is more to be learned about the availability of vitamin $\mathrm{K}$ from different sources, both exogenous (foods) and endogenous (bacterial). Studies of the changes in availability with age, and in different physiological and disease states, are also becoming feasible.

\section{THIAMIN}

Thiamin (vitamin $\mathbf{B}_{1}$ ) is a water-soluble, $\mathbf{B}$ complex vitamin with an essential role in carbohydrate metabolism and neural function (Davis \& Icke, 1983). Although thiamin can be synthesized by gut microflora, this is insufficient to contribute significantly to body requirements. Pure thiamin is well absorbed, but there is little information on the bioavailability of the vitamin from food sources, as coenzyme complexes.

\section{FOOD SOURCES}

Thiamin is widely distributed in most foods at relatively low concentrations. The richest sources are yeasts, cereals and meats, especially liver. In plant foods, thiamin occurs predominantly free. In animal foods, it occurs almost entirely (95-98\%) in the phosphorylated forms (mono-, di- and triphosphates) with about $80 \%$ as the diphosphate (Gubler, 1991). In food or multivitamin supplements, thiamin hydrochloride or mononitrate is used.

\section{ABSORPTION AND EXCRETION}

Thiamin is readily released. Phosphorylated forms are cleaved in the intestine to the free vitamin. Studies using inverted jejunal sacs have shown that rat and human mucosae absorb thiamin at low concentrations $(<2 \mu \mathrm{M})$ by a saturable, active carrier mediated process with a $\mathrm{K}_{\mathrm{m}} 0 \cdot 16-0 \cdot 38 \mu \mathrm{M}$, similar to the $\mathrm{K}_{\mathrm{m}}$ of thiamin pyrophosphokinase. A close association between transport and phosphorylation has been suggested (Schaller \& Höller, 1974). At higher thiamin concentrations $(5-50 \mu \mathrm{M})$ absorption is via passive diffusion (Hoyumpa et al. 1975, 1982). Active absorption of thiamin across the mucosal cell, therefore, may not be associated with or dependent upon phosphorylation of thiamin. A specific carrier is implied, and supported by a thiamin binding protein in Escherichia coli and rat serum, associated with cellular thiamin transport (Matsuura et al. 1975). This binding protein may also be involved in the distribution of thiamin to critical tissues (Combs, 1992). Ethanol, taken orally or intravenously, inhibits intestinal uptake of thiamin.

Active absorption is greatest in the jejunum and ileum. The intestinal mucosa has a thiamin pyrophosphokinase activity with a $K_{m}$ of the same order as that of carrier mediated absorption. However, the role of thiamin pyrophosphokinase is not fully understood. While most of the vitamin in the intestinal mucosa is phosphorylated, thiamin on the serosal side is mainly in the free form. Thus uptake is dependent either on thiamin phosphorylation/dephosphorylation, or on some other energy dependent mechanism, possibly activated by sodium (Basilico et al. 1979). Thiamin release on the serosal side is dependent on $\mathrm{Na}^{+}$and on the normal function of ATPase.

Thiamin preparations with greater lipid solubility (e.g. allithiamin derivatives such as thiamin propyldisulphide and 5-benzoylthiamin-O-monophosphate (benfotiamine)) are much more readily absorbed than thiamin hydrochloride, and result in higher blood and tissue levels (Baker \& Frank, 1976). Allithiamin derivatives have been used to correct thiamin deficiencies, especially in alcoholics (Nose \& Iwashima, 1965). 
Thiamin is transported into red blood cells by diffusion (Hoyumpa, 1982), while in other tissues it proceeds by the active, carrier mediated process (Matsuura et al. 1975). Whole blood concentrations are $150-350 \mathrm{nmol} / 1,90 \%$ of which is in the red cells and leukocytes. Thiamin has a high turnover rate and is not stored. Even a few days with inadequate intake can lead to signs of deficiency.

Excess thiamin is rapidly excreted in the urine, chiefly as the free vitamin and thiamin monophosphate. In addition, thiamine diphosphate, thiochrome, thiamin disulphide and other metabolites are excreted in small amounts. The relative proportion of metabolites to thiamin excreted increases with decreasing thiamin intake (Pearson, 1967).

\section{FACTORS AFFECTING ABSORPTION AND UTILIZATION}

\section{Food processing}

The vitamin is susceptible to destruction by several factors including neutral and alkaline $\mathrm{pH}$, heat, oxidation and ionizing radiation. Thiamin is very stable at acidic $\mathrm{pH}$ but becomes unstable at $\mathrm{pH}>7$, especially when heated. The protein bound thiamin in animal tissue is more stable. In cereal gains, thiamin is unevenly distributed, being low in endosperm and high in germ. Milling and polishing of brown rice depletes thiamin. Most white rice and flour is re-enriched or fortified with the vitamin. Thiamin is destroyed by sulphites added to vegetables during blanching, by rupture of the methylene-thiazole bond (Gubler, 1991).

\section{Antagonists}

Several thiamin antagonists, which reduce absorption, are analogues that differ in either the thiazole (e.g. pyrithiamin), or pyrimidine (e.g. oxythiamin), rings. Although such compounds bind with thiamin dependent apoenzymes, they are inactive. Other antagonists include chick anticoccidial compounds (e.g. amprolium) which do not have a hydroxyether group and therefore cannot be phosphorylated. The sources and levels of them in foods, and their effect on absorption, are not known.

Thiamin destroying or inactivating enzymes (thiaminases) occur in fish, shellfish, ferns, tea, betel nuts and vegetables. Two types have been isolated, one from fresh fish, shellfish and ferns which catalyses a base exchange involving thiazole, the other a hydrolytic enzyme that hydrolyses the methylene-thiazole bond (cf. thiamine destruction by sulphites; Murata, 1965). Although thiaminases in raw fish are heat labile, this can still cause deficiency if consumption is high, as in Japan.

Heat stable antagonists are present in several plants (e.g. ferns, tea, nuts) and include hydroxypolyphenols (e.g. caffeic, chlorogenic and tannic acids) (Somogyi, 1971). They occur in fruits (blueberries, red currants), vegetables (Brussels sprouts, red cabbage), nuts, tea and coffee. Thiamin disulphide production indicates destruction of thiazole. Other thermostable inactivators include flavonoids (e.g. rutin, quercetin), found in brassicas, and haemins in animal products.

\section{Alcohol, diseases and drugs}

Excessive intake of alcohol inhibits intestinal ATPase involved in absorption of thiamin. Its utilization is impaired by liver dysfunction (hepatitis, cirrhosis). Drugs that cause nausea, induce diuresis, or increase intestinal motility decrease its availability.

\section{Smoking and age}

Older studies have shown that nicotine decreases tissue thiamin concentrations in the developing chick embryo (Kato, 1959) and excretion is markedly reduced in heavy smokers (Strauss \& Scheer, 1939; Rafsky et al. 1947). Elderly persons may have increased 
requirements for $\mathrm{B}$ group vitamins, including thiamin, owing to a variety of factors including poor eating habits and malabsorption. Old rats require more thiamin $/ \mathrm{g}$ food to maintain blood and tissue thiamin concentrations than younger ones (Mills et al. 1976). Thiamin transport across the intestine is lower in older animals (Nishino \& Itokawa, 1977).

\section{Other nutrient interactions}

The amount of carbohydrate in the diet influences thiamin requirements. Other nutrients (e.g. $\mathrm{Mg}^{2+}, \mathrm{Ca}^{2+}, \mathrm{B}$ group vitamins) can affect thiamin metabolism and function in rats (Howard et al. 1974; Kimura \& Itokawa, 1977; Nishino \& Itokawa, 1977).

\section{CONCLUSIONS}

Both free and phosphorylated forms of thiamin are readily released from animal and plant foods. Phosphorylated forms are cleaved in the intestine to the free vitamin which is absorbed by an active, carrier mediated process at low concentrations, and by passive diffusion at higher concentrations. Thiaminases in foods can lead to loss of vitamin activity by destruction of the vitamin, or conversion to a form that is biologically unavailable. Metabolic demands for thiamin are increased by diets rich in carbohydrate. Alcohol inhibits absorption.

\section{RIBOFLAVIN}

Riboflavin or vitamin $\mathbf{B}_{2}$, a water-soluble vitamin of the $\mathrm{B}$ group, is an essential dietary component for man, although some animal species can obtain sufficient from their intestinal flora via coprophagy (Prentice \& Bates, 1980). Free riboflavin, and the free coenzymes riboflavin-5-phosphate (usually known as flavin mononucleotide), and the adenyl derivative of FMN (known as flavin adenine dinucleotide), are readily available for absorption and utilization by animals and man, whereas those flavin coenzymes which are linked to enzymes covalently, usually through the 8-methyl group, are not available.

\section{FOOD SOURCES}

Rich sources of riboflavin and its coenzymes include offal, yeast hydrolysate, milk, dairy products, and eggs. Because ungerminated grains, especially polished rice, are poor sources, those communities which rely heavily on simple rice dishes are at high risk of deficiency. Milk and eggs contain riboflavin bound to a carrier protein; hydrolysed products such as yeast hydrolysate and vitamin supplements contain free riboflavin. Other foods contain a major proportion of their riboflavin as coenzymes bound to enzymes, $60-90 \%$ occurring as FAD.

\section{RELEASE AND ABSORPTION}

Riboflavin phosphate and FAD are hydrolysed by various types of phosphatase in the lumen of the intestine (Akiyama et al. 1982) thus yielding free riboflavin, which is then absorbed in the upper ileum, mainly by a sodium dependent saturable transport mechanism (McCormick, 1972; Jusko \& Levy, 1975; McCormick, 1989). After riboflavin phosphate is dephosphorylated to riboflavin in the intestinal lumen, free riboflavin is then rephosphorylated in the mucosal cells during transport, but is dephosphorylated again once it enters the bloodstream (Jusko \& Levy, 1975). In humans, absorption is linear for single doses up to around $30 \mathrm{mg}$ riboflavin, if given with a meal. Bile salts, and factors which 
increase the transit time, increase absorption (Jusko \& Levy, 1975; Mayersohn et al. 1969). In riboflavin saturated subjects, $15-60 \%$ of an oral dose between 5 and $30 \mathrm{mg}$ is rapidly excreted in the urine. Some synthetic fatty acid esters of riboflavin are more readily absorbed than riboflavin itself (Jusko \& Levy, 1975). In everted jejunal segments of rat intestine, physiological amounts of riboflavin are transported by a carrier mediated saturable mechanism. At higher concentrations, diffusion predominates (Said et al. 1985; Daniel et al. 1983). The large bowel may absorb small amounts of riboflavin (Jusko \& Levy, 1975), but it is much less efficient than the ileum in this respect.

An active transport system for efflux of riboflavin is present in the choroid plexus (Spector \& Boose, 1979), and there are also specific transport systems in liver (Aw et al. 1983), kidney (Spector \& Boose, 1982) and placenta (Dancis et al. 1985). A specific riboflavin binding protein which appears to play an important role in riboflavin transport from maternal to fetal circulation has been identified in pregnant rats and in cows, and preliminary indications suggest that it may also occur in humans (Murty \& Adiga, 1982; White \& Merrill, 1988).

\section{EXCRETION}

Amounts of riboflavin that are absorbed in excess of immediate needs, and in excess of the renal tubular reabsorption threshold, are rapidly excreted in the urine. Various hormonal, chemical and disease factors affect urinary excretion (Jusko \& Levy, 1975). Loss through biliary excretion is a minor pathway in humans (Jusko \& Levy, 1975); secretion into breast milk is significant, but is smaller in humans than the cow and rat.

\section{ANTAGONISTS AND HOMEOSTATIC INFLUENCES}

In animals, certain structural analogues of riboflavin, notably galactoflavin (7,8-dimethyl10-(d-1'-dulcityl)-isoalloxazine), compete and give rise to functional deficiency (Warkany, 1975). Chlorpromazine, tricyclic antidepressants (Pinto et al. 1981), and certain antimalarial drugs (Dutta et al. 1985) have structural analogies with riboflavin, and may also compete either for intestinal absorption or for flavokinase. Boric acid in large amounts can cause deficiency, and other substances can alter availability in various ways (Jusko \& Levy, 1975). Experimental uraemia can interfere with riboflavin absorption (Vaziri et al. 1985). In one human study, increasing efficiency of absorption occurred with age, in parallel with decreasing gut transit rate (Jusko \& Levy, 1975), but no age changes were detected in an animal model (Said \& Hollander, 1985), and this requires further study.

\section{CONCLUSION}

Non-covalently bound riboflavin and its coenzymes in food are rapidly and efficiently absorbed by a saturable mechanism, especially if given with a meal, and the excess over immediate needs is rapidly excreted in the urine. At low intakes, the body efficiently conserves tissue flavins, but certain xenobiotics and hormonal effects can influence riboflavin status, usually by altering flavokinase activity.

\section{VITAMIN $B_{6}$}

Vitamin $B_{6}$ is the generic name of three vitamers: pyridoxol, pyridoxal and pyridoxamine, which can be interconverted and occur either free or as phosphorylated forms in various plant and animal food products. Good sources of pyridoxine are vegetables, cereals, seeds 
(nuts) and meat products. Problems of vitamin $B_{6}$ bioavailability can be subdivided into external and internal factors, affecting vitamin $\mathbf{B}_{6}$ or its metabolites and hence utilization.

External factors are food components and their environment that may impair the release of the vitamin, thus affecting digestibility and gastrointestinal absorption of $\mathbf{B}_{6}$. Some of these food borne determinants are inherent; others can arise from food processing. $B_{6}$ bioavailability may also be affected by internal factors, including malabsorptive states, the retention capacity of organs and tissues, interactions with nutrients and non-nutrients, or inborn errors of $B_{6}$ metabolism. The absorption of free $B_{6}$ from the intestine is, in contrast to other $B$ vitamins, unlimited and not subjected to saturation kinetics. High oral $B_{6}$ doses of more than $1 \mathrm{~g}$ /day may cause neuropathies.

\section{FOOD PROCESSING; BOUND B}

Heating of foods can cause $B_{6}$ decomposition or a loss of $B_{6}$ availability through formation of reaction products. The more reactive vitamers pyridoxal and pyridoxamine and their phosphates can bind to amino $\left(\mathrm{NH}_{2}-\right)$ or sulphydryl ( $\left.\mathrm{SH}-\right)$ groups of amino acid residues from proteins, forming aldimines or Schiff bases, which may be stabilized by chelating in presence of metal ions. Under reducing conditions a stable aldimine or ketimine is formed, e.g. pyridoxyl- $\epsilon$-aminolysine.

The protein bound forms have a low availability in man. In rat bioassay studies pyridoxyl- $\epsilon$-aminolysine was found to possess approximately $50 \%$ activity of the free form and for man may even have some antivitamin B $_{6}$ activity (Gregory \& Kirk, 1977; Gregory, 1980). Cysteine bound pyridoxal was identified in heat sterilized milk. Partial destruction of $B_{6}$ during sterilization and the low availability of the remaining bound vitamin resulted in clinical deficiency symptoms in infants fed a commercially sterilized milk formula (Coursin, 1954; Davies et al. 1959). Similarly, pyridoxamine can react with carbonyl compounds of reducing sugars and in the presence of ascorbic acid the inactive 6-hydroxypyridoxine can be formed (Tadera et al. 1986).

A few years ago it was demonstrated by several authors that vitamin $B_{6}$ can react with equimolar amounts of glucose to form 5-O- $\beta$-glucopyranosylpyridoxine (PNG) first identified in rice bran (Gregory \& Ink, 1987; Reynolds, 1988). Studies with rats using intrinsic and extrinsic labelling indicated that purified PNG was relatively well absorbed, but about $80 \%$ of the glucoside was rapidly excreted in urine. Only $20-30 \%$ bioavailability of the glucoside relative to pyridoxol was found (Gregory et al. 1991 b; Gilbert \& Gregory, 1992). In man, however, PNG was $58 \%$ utilized as determined with isotopes. When intravenously administered, the glucoside was only $30 \%$ available, suggesting a role of $\beta$ glucosidases of the intestinal mucosa, microflora or both. The glucoside also seems to alter metabolism and in vivo retention of free pyridoxol, and it may retard the utilization of other non-glycosylated $\mathrm{B}_{6}$ vitamers (Gregory et al. 1991 b; Gilbert \& Gregory, 1992).

Glucosidic $\mathrm{B}_{6}$ occurs only in plant material, and ranges from $8 \%$ to $50 \%$ of total $\mathrm{B}_{6}$. Plant components with storage functions, such as root vegetables, exhibit the highest glucoside contents (Reynolds, 1988; Bitsch \& Schramm, 1992). In some seeds, such as wheat, sunflower, lucerne and mung bean, two glucosidic forms are found. Higher conjugated glucosides were found in rice bran (Tadera et al. 1988). Glucosidic pyridoxol seems relatively stable, and $2 \mathrm{~h}$ autoclaving at $121^{\circ} \mathrm{C}$ in acid was required for appreciable hydrolysis (Bitsch \& Schramm, 1992).

Several authors estimated $70-80 \%$ bioavailability of $\mathbf{B}_{6}$ in the average American diet, based on total (including glycosylated) $B_{6}$ content (Kabir et al. 1983; Reynolds, 1988). Although glucosidic $\mathbf{B}_{6}$ was not detected in animals, a study on lactating women from a 
vegetarian population revealed small amounts in breast milk. The glucoside content was correlated between food and breast milk samples (Reynolds, 1988).

\section{INTERACTIONS WITH NUTRIENTS AND DRUGS}

In addition to naturally bound forms and those produced by food processing, there are also $\mathbf{B}_{6}$ antagonists. Some can compete for absorption; others inactivate $\mathbf{B}_{6}$ vitamers by complexing pyridoxal and pyridoxal phosphate, or by acting as structural analogues, e.g. isoniazid, penicillamine, cycloserine and carbonyl drugs such as benzerazide and carbidopa. Coadministration of pyridoxamine counteracts these effects. Theophylline used in asthma therapy is also thought to act as a pyridoxal phosphate antagonist (Merrill \& Henderson, 1987). It is not clear in every case what is the principal site of interaction in vivo.

$A$ close connection exists between vitamin $\mathbf{B}_{6}$ and protein turnover. In animal experiments, the level and quality of dietary protein affected the $\mathrm{B}_{6}$ retention capacity of liver and muscle (Sampson \& Chung, 1991; Trumbo, 1991). The ratio, 0.015-0.02 mg vitamin $B_{6} / g$ dietary protein, has been suggested as the basis of human vitamin $\mathbf{B}_{6}$ recommended intake (Hansen et al. 1991).

Riboflavin dependent enzymes are involved in the conversion of pyridoxine to pyridoxal phosphate and in the oxidation of pyridoxal to 4-pyridoxic acid, so riboflavin status may affect the metabolic availability of $\mathbf{B}_{6}$ vitamers, as was suggested in experiments with rats (Lakshmi \& Bamji, 1979).

\section{CONCLUSION}

While $\mathbf{B}_{6}$ vitamers in animal foods are well absorbed and bioavailable, a major part of $\mathbf{B}_{6}$ in plant foods is glucosidically bound with a low bioavailability for man. More research is needed in order to clarify the contribution of plant food to human $B_{6}$ supplies.

\section{NIACIN}

The term niacin includes nicotinic acid, nicotinamide, $\mathrm{NAD}(\mathrm{H})^{+}$, and $\mathrm{NADP}(\mathrm{H})^{+}$. Humans are able to synthesize niacin from tryptophan (Henderson, 1983; Bender \& Bender, 1986). Therefore the niacin content of foods is usually expressed as niacin equivalents (niacin $+($ tryptophan/60)).

\section{FOOD SOURCES}

Niacin is widely distributed in foods of plant and animal origin. In typical western diets the most important sources of preformed niacin are meat and meat products, cereals, dairy products, beverages and eggs (Deutsche Gesellschaft für Ernährung, 1988). Niacin is resistant to heat, light, storage, and oxygen. In foods, niacin occurs mainly in its coenzyme forms, e.g. $\mathrm{NAD}(\mathrm{H})^{+}$. To some extent $\mathrm{NAD}\left(\mathrm{H}^{+}\right)$is hydrolysed to nicotinamide during food processing. In cereals the main part of niacin is bound as niacytin. Niacytin is not a well defined compound, but is a mixture of different peptides, proteins and carbohydrates (Mason et al. 1973). In some cereals niacin is only partly available. In maize, at least $70 \%$ of the niacin is unavailable, unless it is treated with alkali (Carter \& Carpenter, 1982; National Research Council, 1989). In coffee beans there are high concentrations of trigonellin (1-methyl nicotinic acid) from which nicotinic acid can be liberated by roasting 
(Baessler et al. 1992). Therefore coffee can contribute significantly to niacin intake. Naturally occurring antagonists of niacin are rare, but some synthetic antagonists exist (Henderson, 1983). Biosynthesis of niacin by gut flora may occur, but subsequent absorption is uncertain. A lactating woman typically secretes $1.0-1.3 \mathrm{mg}$ preformed niacin daily in $750 \mathrm{ml}$ milk (National Research Council, 1989).

\section{RELEASE AND ABSORPTION}

$\mathrm{NAD}(\mathrm{H})^{+}$is hydrolysed by an intestinal pyrophosphatase to nicotinamide ribonucleotide and riboside, which accumulate in the lumen. Conversion to nicotinamide is the rate limiting step. There is no deamination to nicotinic acid (Henderson, 1983). Nicotinamide is rapidly absorbed in the stomach and small intestine (Bechgaard \& Jespersen, 1977). At low concentrations niacin is absorbed by a sodium dependent facilitated diffusion, whereas higher concentrations are mainly absorbed by passive diffusion (Sadoogh-Abasian $\&$ Evered, 1980). Physiological doses of niacin are nearly completely absorbed. If high doses of niacin (e.g. $3 \mathrm{~g}$ ) are ingested, $85 \%$ is found in urine (Friedrich, 1987). To achieve a slow elimination of niacin from blood plasma, nicotinic acid esters can be used. When $700 \mathrm{mg}$ are given, $75 \%$ of the nicotinic acid is absorbed from such esters (Friedrich, 1987). Slow release forms of niacin have been tested for pharmacological benefits.

\section{EXCRETION}

Urinary metabolites in humans are very similar after oral loads of nicotinamide or nicotinic acid respectively (Mrochek et al. 1976). After doses in the 100-3000 $\mathrm{mg}$ range the main metabolites were $N^{\mathbf{1}}$-methyl-2-pyridone-5-carboxamide, $N^{\mathbf{1}}$-methylnicotinamide, and nicotinuric acid. The latter two increase with higher doses. Of a physiological dose of niacin, $40 \%$ is eliminated via urine within $24 \mathrm{~h}$ (Baessler et al. 1992). An enterohepatic cycle exists. Nicotinamide enters the gastrointestinal tract via bile; it is partly deaminated microbiologically to nicotinic acid. Nicotinamide and nicotinic acid are then re-absorbed and converted to $\mathrm{NAD}(\mathrm{H})^{+}$.

\section{SYNTHESIS FROM TRYPTOPHAN}

Part of the tryptophan in the diet can be converted to niacin (Bender \& Bender, 1986). Indeed, for an adult in nitrogen balance a typical protein intake can provide more than enough tryptophan to meet niacin requirements by endogenous synthesis of NAD, with no need for any preformed dietary niacin. Analysis of urinary metabolites revealed a mean yield of $1 \mathrm{mg}$ niacin from c. $60 \mathrm{mg}$ (range $39-86 \mathrm{mg}$ ) tryptophan (Horwitt et al. 1981; National Research Council, 1989). The rate of conversion is controlled by hormones (Wolf, 1971), and is elevated in pregnancy and by oral contraceptives (Horwitt et al. 1981). It is regulated by nicotinate-nucleotide pyrophosphorylase (carboxylating) (EC 2.4.2.19), but synthesis may be reduced by leucine at the kynureninase ( $E C$ 3.7.1.3) step. It depends on a sufficient supply of riboflavin and pyridoxine (Satyanarayana \& Narasinga Rao, 1980). A typical tryptophan content of proteins is $c .1 \%$ (National Research Council, 1989).

\section{METABOLISM AND TRANSPORT BETWEEN TISSUES}

Absorbed nicotinamide is first accumulated by liver and erythrocytes, and is converted to $\operatorname{NAD}(\mathrm{H})^{+}$. 


\section{CONCLUSIONS}

Niacin is a rapidly and nearly completely absorbed vitamin and is easily transformed to its coenzyme forms $\mathrm{NAD}(\mathrm{H})^{+}$and $\operatorname{NADP}(\mathrm{H})^{+}$. It is very stable under nearly all conditions and is ubiquitously distributed in foods from both animal and plant origin. Biosynthesis from dietary tryptophan also contributes to the supply.

\section{FOLATE}

Folate is the generic term for a B vitamin which is essential for one-carbon transfer reactions in many metabolic pathways, including purine and pyrimidine metabolism and amino acid interconversions. It exists primarily as reduced one-carbon substituted forms of pteroylpolyglutamates. Naturally occurring reduced folates are light and heat sensitive and destroyed by oxidation. Some is lost during cooking. Antioxidants, e.g. ascorbic acid, can prevent oxidation.

The most important food sources are liver, egg and green vegetables such as cabbage, Brussels sprouts, broccoli, lettuce and spinach. Yeast, bran, yogurt and orange juice also contain high levels. The polyglutamyl form of folate is $c .80 \%$ of dietary folate and must be cleaved to monoglutamate before absorption. In milk, folate is bound to a specific folate binding protein.

\section{ABSORPTION OF SYNTHETIC MONO- AND POLY-GLUTAMYL FOLATES}

Monoglutamate folates are absorbed by an active energy dependent carrier mediated process at physiological concentrations, and by passive diffusion at higher concentrations (Selhub et al. 1984). Absorption takes place mainly in the jejunum and is markedly influenced by $\mathrm{pH}$, with a maximum at $\mathrm{pH} 6.3$ and sharp decline between 6.3 and 7.6 (Russell et al. 1979). The $\mathrm{pKa}$ and $\mathrm{pH}$ affect the proportions of ionic and non-ionic forms; non-ionic forms facilitate diffusion across the cell membrane.

The polyglutamate folates must be cleaved to monoglutamates before uptake in the intestinal epithelial cells (primarily in the jejunum) by a pteroylpolyglutamate hydrolase, or folate conjugase. Reisenauer et al. (1977) reported two separate folate conjugase activities in human jejunal mucosa, one soluble and intracellular and the other membrane bound and concentrated in the brush border. Human brush border conjugase is a zinc dependent exopeptidase with optimum activity at $\mathrm{pH} 6.5$ catalysing stepwise hydrolysis of polyglutamyl folates. It plays a major role in the digestion of dietary folate, and zinc deficiency may affect folate bioavailability by impairing folate conjugase activity (see Canton \& Cremin, 1990). Human intracellular folate conjugase is most active at $\mathrm{pH} 4.5$, and its function in absorption is unclear. In contrast to man, the pancreas in chickens and rats provides a rich source of conjugase (Halstead, 1990), suggesting the lumen as the main site of hydrolysis in these species. Some studies indicated a lower (70-80\%) availability of polyglutamate compared with monoglutamate folate (Halstead, 1990). These human studies used a jejunal perfusion technique and labelled synthetic forms of folic acid. Using plasma response, Pietrzik (1993) showed that pteroylheptaglutamic acid was absorbed to $70 \%$ of pteroylmonoglutamic acid following a single oral dose equivalent to $1000 \mu \mathrm{g}$ pteroylmonoglutamic acid. By using stable isotopes, ${ }^{2} \mathrm{H}$-monoglutamyl folate and ${ }^{2} \mathbf{H}-$ hexaglutamyl folates, Gregory et al. $(1991$ a) showed the latter to be approximately half as available as the monoglutamate. Oxidized folates were better absorbed than reduced forms. 
Oxidized folates in physiological amounts become reduced in passing through the intestinal mucosa. At higher concentrations, reduction occurs in the liver, which is the major tissue where folates are stored as polyglutamates. All intracellular folate occurs in polyglutamyl forms, whereas folates are transported in plasma in the monoglutamyl form.

\section{AVAILABILITY OF FOOD FOLATES}

Data on the absorption of dietary folate in man are based mainly on an assessment of bioavailability by urinary excretion after known intakes of synthetic folic acid and presaturation of tissues with repeated folate doses. After ingestion of banana, lima beans, liver and egg, uptake of folate exceeded $70 \%$ compared with synthetic folic acid. For the majority of food items, uptakes of $40-70 \%$ of that for pteroylmonoglutamic acid were observed. The lowest figures were seen for wheat germ, yeast, tomatoes and orange juice. Tamura \& Stokstad (1973) concluded that bioavailability of folates from orange juice was low due to inhibition of intestinal conjugase by the low $\mathrm{pH}(3 \cdot 2)$ of orange juice. However, they used unphysiologically high amounts of orange juice in their meals $(2400 \mathrm{ml})$. When physiological quantities of orange juice were given to human subjects, the bioavailability of folate in orange juice was equal to that of pteroylmonoglutamate (Rhode et al. 1983). Yeast is rich in polyglutamates and several studies indicate poor absorption (Tamura et al. 1973; Babu \& Srikantia, 1976).

Bioavailability data have also been obtained by a rat bioassay. This requires depletion of tissue folates by a folate deficient diet, followed by a test diet containing food folate for 1-2 weeks. The animals are then killed and folates measured in liver, kidney, plasma, erythrocytes or intestinal mucosa. With this model, availability of dietary folates generally exceeds $80 \%$, with no values below $58 \%$. The lowest figures were reported for wheat germ, cabbage and broccoli (Hoppner \& Lampi, 1986; Abad \& Gregory, 1987; Clifford et al. 1990). Foods rich in polyglutamates showed the lowest bioavailability. In contrast, yeast folate with a high proportion of polyglutamates was well utilized in this model (Hoppner \& Lampi, 1986).

\section{MILK FOLATE BINDING PROTEIN}

In milk, the naturally occurring folate is protein bound (Ghitis, 1967; Wagner, 1985). The physiological role of these folate binding proteins is unclear. Ford et al. (1969) suggested that in milk these proteins may act in the mammary gland as a trapping agent for folate. After ingestion by the infant, they could prevent uptake by intestinal bacteria, and might promote the transport of folate across the mucosa. This latter proposal was supported by the work of Salter \& Blakeborough (1988).

Bound folate may be absorbed in a manner different from free folate. While free monoglutamate is absorbed in the jejunum, protein bound folate is mainly absorbed in the ileum and at a much slower rate (Said et al. 1986) which may improve bioavailability.

\section{DIETARY FIBRE AND MATRIX EFFECTS}

A negative effect of wheat bran on availability of polyglutamyl folate has been reported (Keagy et al. 1988) both in rats and humans. Ion exchange may occur between the folates and wheat bran which reaches the colon faster than other types of fibre. Data for monoglutamyl folate are inconsistent. Ristow et al. (1982) found little or no binding to purified dietary fibre, using equilibrium dialysis. Matrix effects by lima beans, cabbage and 
yeast indicate that bioavailability depends on the dietary level. Conjugase inhibitors have been reported in pulses, yeast and cabbage (Butterworth et al. 1974).

\section{EXCRETION}

Faecal folate levels are sometimes higher than intakes, presumably reflecting folate biosynthesis by the microflora of the lower gastrointestinal tract. Bile contains high levels of folate, owing to enterohepatic circulation. Most folate in bile is reabsorbed, but $c .100 \mu \mathrm{g}$ is lost daily through incomplete absorption (Brody et al. 1984). In animals, bile duct cannulation for only $6 \mathrm{~h}$ leads to a $60-70 \%$ fall in serum folate (Steinberg et al. 1979).

\section{CONCLUSIONS AND FUTURE RESEARCH PRIORITIES}

More information is needed about the requirements of people with elevated demands, e.g. pregnant and lactating women, the elderly, slimmers with a low energy intake, and people with gastrointestinal disorders or using drugs such as diphenylhydantoin, salicylazosulphapyridine. Ethanol may also cause malabsorption of folate (Halstead, 1990).

Human data are limited to two studies performed twenty years ago in which urinary excretion after presaturation was measured, after single food items and in groups of less than ten subjects. These showed wide individual variations and hence low reliability, with an overall absorption from mixed diets of about $70 \%$ (Tamura \& Stokstad, 1973; Babu \& Srikantia, 1976).

Further research is needed, with more sensitive and specific methods. Stable isotopes have enabled availability studies in man over physiologically relevant ranges (Gregory et al. 1991 a). Improvements in analysis of different forms of folates, absorption kinetic studies and in vitro absorption techniques for dietary interactions and effects of food processing are now needed.

\section{VIT AMIN B 12 $_{12}$}

Vitamin $\mathbf{B}_{12}$ comprises a number of active metabolites, which differ only in the $\beta$-ligand on the central cobalt. This ligand can be $\mathrm{CH}_{3}$ (methylcobalamin) or adenosyl (adenosylcobalamin) in the human body or alternatively $\mathrm{OH}$ (hydroxocobalamin) or $\mathrm{CN}$ (cyanocobalamin) in pharmaceuticals owing to their greater stability. The latter are most stable at $\mathrm{pH} 4-4 \cdot 5$. Cobalamins can be destroyed by heavy metals or by strong oxidizing or reducing agents (like ascorbate). They are sensitive to light, but relatively stable to heat.

\section{VITAMIN B ${ }_{12}$ IN FOOD}

Only microorganisms are able to synthesize cobalamin and therefore higher plants contain $B_{12}$ only if processed microbiologically or contaminated. Food from animal origin (especially liver and kidney) contains $\mathrm{B}_{12}$. Other rich sources are fish, milk and eggs. Some foods or microorganisms contain other corrinoids, with varying biological activity, some of which may have antivitamin activity. Paradoxically, some compounds with growth factor activity for Lactobacillus leichmannii are described as having $\mathbf{B}_{\mathbf{1 2}}$ activity even if they have none for man (Herbert, 1988). Non-vegetarian humans typically have intakes in the region of $1-10 \mu \mathrm{g} / \mathrm{d}$, usually considerably greater than the requirement, and therefore accumulate a reserve (typically $1-2 \mathrm{mg}$ ) of $B_{12}$ in the liver (Heinrich \& Gabbe, 1990). Smokers may develop a secondary deficiency associated with conversion of $B_{12}$ to the cyano form (Linnell et al. 1968; Shaw et al. 1987). 


\section{ABSORPTION}

There are two separate mechanisms for the absorption of vitamin $B_{12}$. In the active physiological one ingested $B_{12}$ is freed from proteins by gastric acid and enzymes, and then bound to haptocorrin (also called $\mathrm{R}$-protein). The $\mathrm{B}_{12}$-haptocorrin complex is destroyed by trypsin, and $B_{12}$ is transferred to intrinsic factor (IF, synthesized by gastric parietal cells), to form the $\mathrm{B}_{12}-\mathrm{IF}$ complex. Ileal mucosa cell receptors bind the $\mathrm{B}_{12}-\mathrm{IF}$ complex, take up the cobalamin and set the IF free. $\mathrm{Ca}^{2+}$ and a $\mathrm{pH}$ of 6 or higher are necessary to release cobalamin. This active mechanism depends on IF, and on the function of the exocrine pancreas and the ileal receptors. In a normal subject, the number of receptors limits absorption. Absorption is affected by gastrectomy, lack of intrinsic factor or trypsin, or intestinal infections. Atrophic gastritis, especially in elderly people, can lead to $\mathrm{B}_{12}$ deficiency.

The contribution of active and passive mechanisms to total absorption depends on the quantity of vitamin $B_{12}$ (Heinrich \& Wolfsteller, 1966). IF can transport up to $1.5 \mu \mathrm{g} \mathrm{B}_{12}$ at a time; passive diffusion plays a role for higher doses. $\mathrm{B}_{12}$ is not absorbed in the colon (Herbert, 1988) and gut bacteria typically produce non-cobalamin $B_{12}$ analogues.

\section{RETENTION}

There is a difference in retention between $\mathrm{CN}-\mathrm{Cbl}$ and $\mathrm{OH}-\mathrm{Cbl}$. Most pharmacological preparations contain $\mathrm{CN}-\mathrm{Cbl}$, owing to its greater stability. The conversion of $\mathrm{CN}-\mathrm{Cbl}$ into the natural forms in the human body takes several days. OH-cobalamin is also used in pharmacological preparations and is better retained by the human body. Two phases can be differentiated in the elimination of parenterally administered $\mathrm{OH}-\mathrm{Cbl}$ : during the first 5-7 h, serum concentrations decline rapidly (distribution phase), while during the elimination phase (half time of elimination 21-29 h) serum concentrations decline more slowly (Loew et al. 1988). Differences between $\mathrm{CN}-\mathrm{Cbl}$ and $\mathrm{OH}-\mathrm{Cbl}$ might be due to a different rate of protein binding, leading to gradual accumulation of $\mathrm{OH}-\mathrm{Cbl}$ (Loew, 1991). Plasma levels of $\mathrm{CN}-\mathrm{Cbl}$ after parenteral doses decline with a half life of $7 \mathrm{~h}$.

Vitamin $B_{12}$ is very effectively reabsorbed in the ileum (hepato-biliary recirculation); this is interpreted by some authors as a regulatory mechanism to exclude analogues, which are reabsorbed less effectively (Kanazawa \& Herbert, 1982; Herzlich \& Herbert, 1984). The hepato-biliary recirculation is a major reason why strict vegetarians become $\mathbf{B}_{12}$ deficient only after several years of very low dietary intake of $B_{12}$. Excretion through the kidneys $(0-0.25 \mu \mathrm{g} / \mathrm{d})$ is lower than excretion in bile.

\section{CONCLUSION}

Further studies are needed on the factors which determine the release of protein bound $\mathrm{B}_{12}$ in food, and on the diversity of forms of available $B_{12}$ in foods and contamination sources.

\section{BIOTIN}

In humans, biotin (vitamin $\mathbf{B}_{\mathbf{8}}$ or $\mathbf{H}$ ) acts as cofactor for at least four carboxylases, which are key enzymes of intermediary metabolism, namely pyruvate carboxylase $(E C 6.4 .1 .1)$, propionyl-CoA carboxylase ( $E C$ 6.4.1.3), methylcrotonyl-CoA carboxylase $(E C$ 6.4 . 1.4) and acetyl-CoA carboxylase (EC 6.4.1.2) (Wood \& Barden 1977). Biotin $\left(\mathrm{C}_{10} \mathrm{H}_{16} \mathrm{O}_{3} \mathrm{~N}_{2} \mathrm{~S}\right)$ 
comprises an imidazolidone ring fused with a tetrahydrothiopene ring bearing an aliphatic chain with five asymmetric carbon atoms. There are several known derivatives (oxybiotin, biotin sulphoxide, biocytin, biotin sulphone, biotinol), but of these only biocytin ( $\epsilon-N$ biotinyl-L-lysine) is found in nature and has vitamin activity. The lysine bond is a link to protein (Marquet, 1977; Cowan, 1984). Avidin, a glycoprotein component of egg white (hen, duck, goose, turkey), has a great affinity for biotin, with which it combines stoichiometrically. This complex, which resists the digestive enzymes, is unavailable for intestinal absorption, unlike biocytin (Bonjour, 1977; Gravel et al. 1980).

\section{ABSORPTION AND EXCRETION}

Biotin metabolism in mammals involves gastrointestinal absorption, transport and catabolism. Two major sources for man are the diet and the biotin producing flora in the intestinal tract distal to the caecum. The intake from all sources is about $150-300 \mu \mathrm{g} / \mathrm{d}$. The pancreatic enzyme, biotinidase, probably splits the biotin-lysine bond, releasing the vitamin in the intestinal lumen. The mechanisms of intestinal transport are not completely known. Transport occurs in the proximal small intestine and jejunum, coupled with $\mathrm{Na}^{+}$ and against the concentration gradient (Spencer \& Brody, 1964; Berger et al. 1972; Said et al. 1987). Urinary levels are approximately $160 \mathrm{nmol} / 24 \mathrm{~h}$ or $70 \mathrm{nmol} / 1$. A blood plasma, or serum level of about $1500 \mathrm{pmol} / \mathrm{l}$ suggests an adequate supply of biotin in man (Bonjour, 1984).

\section{DIETARY SOURCES}

Biotin is widely present in meats (chicken, pork, beef, lamb), vegetables (cauliflowers, mushrooms, carrots, tomatoes, spinach, beans and peas) and fruits (apples, oranges), and it is found in milk (human and bovine), in cheese, eggs and marine fish. The human requirement for biotin is not known, and recommended dietary allowances for it have not been formulated. A 'safe and adequate intake' has been proposed by the Food and Nutrition Board of the U.S. National Academy of Sciences (Food and Nutrition Board, 1989): for adults $0 \cdot 1-0 \cdot 4 \mu \mathrm{mol}(30-100 \mu \mathrm{g})$ per day, based on typical intakes in Western society. No depletion-repletion studies are available, to define human requirements. There are no detailed studies which indicate the contribution from bacterial synthesis in humans.

\section{REQUIREMENTS AND NUTRITIONAL STATUS}

Knowledge about biotin requirements is limited to the range of usual intakes by human populations in which deficiency is not observed. Clearcut deficiency has only been recorded in people eating large quantities of egg white. For this reason, intake recommendations can only reflect the biotin content of human diets.

Plasma (or serum) levels and urinary biotin excretion are used to evaluate biotin nutritional status in humans. Biotin deficiency has been demonstrated in certain infants with inborn metabolic errors, but cases of human deficiency are rare. Deficiency may occur in $(a)$ individuals receiving long term parenteral nutrition without biotin (Velazquez et al. 1990); (b) prolonged feeding of undenatured egg white, rich in avidin (Bonjour, 1977; Gravel et al. 1980; Sweetman et al. 1981); or (c) individuals affected by genetic biotinidase deficiency (Cowan et al. 1979; Munnich et al. 1981; Thoene \& Wolf, 1983; Wolf et al. 1983). Clinical manifestations of induced biotin deficiency are mild and non-specific (nonpruritic dermatitis, seborrhoea, fatigue, muscular pain, anorexia, nausea, anaemia, hypercholesterolaemia). 


\section{CONCLUSION}

Biotin deficiency is rare in humans. Studies of genetic multiple carboxylase deficiencies have permitted research on its metabolic functions. Absorption and catabolism in humans requires further research.

\section{PANTOTHENIC ACID}

Pantothenic acid or vitamin $\mathbf{B}_{5}$ is an essential dietary component for humans, composed of $\beta$-alanine and the dihydroxyacid, pantoic acid. It occurs in both the bound and free form in food, and is ubiquitously distributed. Meat, avocado, broccoli, bran and molasses are excellent sources (Machlin, 1984). It is stable at high temperatures at pH 5-7 (Pike \& Brown, 1975). The Food and Nutrition Board (1989) of the National Research Council concluded that there was insufficient evidence to set a recommended dietary allowance for this vitamin, and proposed a 'safe and adequate intake' of $4-7 \mathrm{mg} / \mathrm{d}$ in adults, and $2.0-3.0 \mathrm{mg} / \mathrm{d}$ in infants, based on usual intakes, but no depletion-repletion studies are available.

\section{RELEASE AND ABSORPTION}

Bioavailability of food pantothenic acid for man ranges from 40 to $61 \%$, with a mean of $50 \%$ (Tarr et al. 1981). Studies in vivo (Reibel et al. 1981) and in vitro (Sugarman \& Munro, 1980) have identified one mechanism of transmembrane transport. In the adipocyte of rat the transport of ${ }^{14} \mathrm{C}$-pantothenate is fast, with a high affinity (half saturation at a concentration of $10^{-5} \mathrm{M}$ ), saturable, specific, and energy and temperature dependent. A specific intestinal transport mechanism, unsaturated at physiological concentration, was therefore proposed (Munnich et al. 1990).

\section{EXCRETION}

No degradation products of pantothenic acid are known (Sugarman \& Munro, 1980); 1-7 $\mathrm{mg} / \mathrm{d}$ of intact pantothenic acid are excreted in the urine. Mean excretion increased from 2.3 to $3.9 \mathrm{mg} / \mathrm{d}$ as intake increased from 5 to $10 \mathrm{mg}$ (Foss, 1981). Excretion of 9.7 and $36.2 \mathrm{mg}$ was reported at 17 and $117 \mathrm{mg} / \mathrm{d}$ intakes respectively (Lin, 1981; Kies et al. 1982).

\section{NUTRITIONAL STATUS AND INDUCED DEFICIENCY}

Deficiency of pantothenic acid occurs only in severe malnutrition (Machlin, 1984); however, deficiency symptoms have been produced by administering a metabolic antagonist, $\omega$-methylpantothenic acid (Bean \& Hodges, 1954; Lubin et al. 1956). The subjects developed a burning sensation in the feet, vomiting, depression, fatigue, insomnia, tenderness in the heels, and muscular weakness. A change in glucose tolerance was also reported, associated with increased sensitivity to insulin and a decrease in antibody production (Hodges et al. 1958). Other antagonists are pantoyltaurine and phenylpantothenate (Machlin, 1984). Whole blood, serum levels and urine pantothenic acid excretion are used to evaluate pantothenic acid status in humans.

\section{CONCLUSION}

The physiological roles of pantothenic acid and coenzyme A are known, but there is a lack of knowledge about intestinal absorption, plasma transport and catabolism. No genetic diseases related to pantothenic acid metabolism are known, probably because the diseases 
would be incompatible with life. Further research is needed on the metabolic pathways of pantothenic acid and coenzyme A.

\section{VITAMIN C}

Vitamin $\mathrm{C}$ exists in three generally recognized forms in living tissues: ascorbate, the nonionizable, oxidized form, dehydroascorbate, and the intermediate oxidation state, ascorbate free radical (also known as semidehydroascorbate or monodehydroascorbate). The stability of the three species diminishes in that order. Ascorbate free radical can only be detected transiently, e.g. by electron spin resonance, but the other two forms exist as food components, and their bioavailability has been studied in some detail. The availability of vitamin $C$ is closely bound up with its stability to oxidation, since it is the least stable of all the vitamins in foods, and its biological activity and retention within the body are also dependent on the linkage with various redox cycles in vivo. A dietary requirement for vitamin $\mathrm{C}$ is encountered only in higher primates and in a few other mammals, birds and insects. Other species normally synthesize it from hexose sugars.

\section{FOOD SOURCES}

It is well established that the most important food sources of vitamin $\mathrm{C}$ are fresh fruit and vegetables, especially soft and citrus fruits, and the growing tips of plants; potatoes can also be a significant source because of the relatively large amount commonly eaten. Ungerminated seeds and the foods made from them contain very little vitamin $C$. Vitamin $\mathrm{C}$ is easily destroyed by exposure to light and oxygen, by prolonged storage, by alkaline cooking conditions, or by exposure to redox transition metals such as iron and copper, unless these are complexed, for instance, within proteins. Ascorbate oxidases, released from vegetables during cutting or wilting, help to destroy vitamin $\mathrm{C}$. Both ascorbate and dehydroascorbate are found in food; the reduced form predominates in fresh food and in the living animal. Analytical methods for vitamin $\mathrm{C}$ in food or tissue extracts may or may not include dehydroascorbate or dioxogulonic acid. Of these two compounds, only the first is biologically active. Ascorbate or its analogue D-isoascorbate (erythrobate) are frequently added to manufactured foods, not only to increase their vitamin $\mathrm{C}$ content but also to protect other oxygen sensitive molecules and thus to prevent discolouration, nitrosamine formation etc. Ascorbate is used in bread making, as a flour improver, but none of it survives in the finished loaf.

\section{INTESTINAL ABSORPTION}

In man and guineapigs, both of which have an absolute requirement for exogenous vitamin $\mathrm{C}$ in their diet, there is an ouabain sensitive sodium dependent saturable active transport system for ascorbic acid at the brush border of the duodenum and upper ileum, and another sodium independent transfer process at the basolateral membrane (Stevenson, 1974; Toggenburger et al. 1979; Hornig, 1981; Patterson et al. 1982; Bianchi et al. 1986; Rose, 1988). In isolated intestinal preparations from guineapigs, active concentration of ascorbic acid against an electrochemical gradient has been demonstrated (Bianchi et al. 1986). Active transport seems absent in rats, rabbits or hamsters, species which do not require a dietary source (Toggenburger et al. 1979).

Dehydroascorbate is absorbed by a carrier mediated passive mechanism, both in the intestinal and in the buccal mucosa (Bianchi et al. 1986; Rose, 1988). In the guineapig it is reduced to ascorbate before reaching the basolateral membrane (Bianchi et al. 1986). 
Since dehydroascorbate is unstable, this may account for poor agreement between studies of its transport.

At low levels of intake vitamin $\mathrm{C}$ is very efficiently absorbed and retained by humans. Divided doses are absorbed more efficiently than a single bolus, and at intakes up to c. $100-180 \mathrm{mg} / \mathrm{d}, 80-95 \%$ is absorbed (Hornig, 1981; Kallner et al. 1977). At higher intakes, the absorption mechanism becomes overloaded, so that of a single $1.5 \mathrm{~g}$ dose only $50 \%$ is absorbed, of $6 \mathrm{~g} 25 \%$ is absorbed and of $12 \mathrm{~g} 16 \%$ is absorbed (Rivers, 1987). At high intakes, and provided the subject is initially near saturation, the absorption efficiency can be estimated by the proportion of the dose that is recovered in the urine within $24 \mathrm{~h}$. Peak excretion is usually at around $4 \mathrm{~h}$ after dosing. The unabsorbed fraction is virtually all destroyed, presumably by bacterial processes, in the lower bowel. Clearly, although gram doses are not very efficiently absorbed, yet the total amount that can be absorbed increases steadily across a wide range of increasing intakes up to a maximum of $c .1 \cdot 2 \mathrm{~g}$ at high single doses (Hornig et al. 1980; Yung et al. 1982; Melethil et al. 1986; Rivers, 1987). Since the amount absorbed also determines the concentration achieved in the tissues, it is possible to increase tissue ascorbate levels progressively, by increasing the intakes to high levels. However, the greatest tissue sensitivity to intake variation occurs over a low intake range, $0-50 \mathrm{mg} / \mathrm{d}$.

\section{TURNOVER AND EXCRETION AND FACTORS WHICH AFFECT AVAILABILITY}

Turnover amounts to $c .3 \% / \mathrm{d}$ of the ascorbate body pool (Baker et al. 1969). Saturation kinetics with vitamin $\mathrm{C}$ at the brush border of the ileum implies that large doses $(1 \mathrm{~g}$ or more) cannot be completely absorbed. Enhanced absorption can, however, be achieved either by dividing the dose or by using a slow release preparation (Yung et al. 1982). Some investigators have claimed that certain food components such as the bioflavonoids can enhance the availability of food ascorbate over that observed with the pure vitamin, possibly by protecting it from oxidation (Vinson \& Bose, 1988). Since the optical isomer of natural ascorbate, D-iso-ascorbate ( $=\mathrm{D}$-erythrobate), is absorbed less efficiently, it is clear that intestinal absorption of L-ascorbate is a stereospecific process (Hornig, 1975). Aspirin apparently inhibits the absorption of ascorbic acid (Basu, 1982), although the precise mechanism is not fully understood.

\section{TRANSPORT AT OTHER SITES}

Most organs concentrate ascorbate from plasma indicating active transport against a concentration gradient. At some sites-white blood cells, the adrenal medulla, brain, connective tissue cells, placenta, kidney, intestine, and the ciliary epithelium of the eye-ascorbate transport predominates (Rose, 1988; Choi \& Rose, 1989; Bergsten et al. 1990). Other tissues appear to transport dehydroascorbate, reducing it to ascorbate within the cell. Ascorbate homeostasis and its failure during conditions such as infection, diabetes and atrophic gastritis require further study (Schorah, 1992).

\section{CONTRASTS BETWEEN GROUPS OF PEOPLE}

Differences in requirements for ascorbate exist between the sexes (Blanchard, 1991), between smokers and non-smokers (Murata, 1991) and possibly between elderly and young adults (Davies et al. 1984; Blanchard et al. 1990). Diabetics may have disturbed ascorbate economy, although the mechanism is uncertain (Schorah, 1992). There is no clear 
consensus on whether these differences are attributable to differences in the efficiency of ascorbate absorption; differences in turnover may be important.

\section{CONCLUSION}

Vitamin $\mathrm{C}$ is absorbed by active transport in man. This transport process is highly efficient at low to moderate intakes, but becomes progressively less efficient at high intakes of single doses. Active transport at other sites, including the kidney, ensures retention of appropriate levels of the vitamin and its characteristic distribution between tissues. Further studies are needed on the factors which determine efficiency of absorption from food, and turnover of vitamin $\mathrm{C}$.

\section{REFERENCES}

Abad, A. R. \& Gregory, J. F. (1987). Determination of folate bioavailability with a rat bioassay. Journal of Nutrition 117, 866873 .

Akiyama, T., Selhub, J. \& Rosenberg, I. H. (1982). FMN phosphatase and FAD pyrophosphatase in rat intestinal brush borders: role in intestinal absorption of dietary riboflavin. Journal of Nutrition 112, 263-268.

Allison, P. M., Mummah-Schendel, L. L., Kindberg, C. G., Harms, C. S., Bang, N. U. \& Suttie, J. W. (1987). Effects of a vitamin K-deficient diet and antibiotics in normal human volunteers. Journal of Laboratory and Clinical Medicine 110, 180-188.

Aw, T. Y., Jones, D. P. \& McCormick, D. B. (1983). Uptake of riboflavin by isolated rat liver cells. Journal of Nutrition 113, 1249-1254.

Babu, S. \& Srikantia, S. G. (1976). Availability of folates from some foods. American Journal of Clinical Nutrition 29, 376-379.

Baessler, K-H., Gruehn, E., Loew, D. \& Pietrzik, K. (1992). Vitamin-Lexikon, pp. 154-173. Stuttgart: Gustav Fischer Verlag.

Baker, E. M., Hodges, R. E., Hood, J., Sauberlich, H. E. \& March, S. C. (1969). Metabolism of ascorbic-1-1 ${ }^{14}$ C acid in experimental human scurvy. American Journal of Clinical Nutrition 22, 549-558.

Baker, H. \& Frank, O. (1976). Absorption, utilization and clinical effects of allithiamins compared to watersoluble vitamins. Journal of Nutritional Science and Vitaminology 22, 63-66.

Barua, A. B., Batres, R. O. \& Olson, J. A. (1989). Characterization of retinyl $\beta$-glucuronide in human blood. American Journal of Clinical Nutrition 50, 370-374.

Basilico, V., Ferrari, G., Rindi, G. \& D'Andrea, G. (1979). Thiamine intestinal transport and phosphorylation: a study in vitro of potential inhibitors of small intestinal thiamine-pyrophosphokinase using a crude enzymatic preparation. Archives Internationales de Physiologie et de Biochimie 87, 981-995.

Basu, T. K. (1982). Vitamin C-aspirin interactions. In Vitamin C: New Clinical Applications in Immunology, Lipid Metabolism and Cancer (International Journal of Vitamin and Nutrition Research, Suppl. 23) $83-90$ [A. Hanck, editor].

Batchelor, A. J. \& Compston, J. E. (1983). Reduced plasma half-life of radio-labelled 25 -hydroxyvitamin $D_{3}$ in subjects receiving a high-fibre diet. British Journal of Nutrition 49, 213-216.

Bauernfeind, J. (1980). Tocopherols in foods. In Vitamin E: A Comprehensive Treatise, pp. 99-167. [L. J. Machlin, editor]. New York: Deckker.

Bean, W. B. \& Hodges, R. E. (1954). Pantothenic acid deficiency induced in human subjects. Proceedings of the Society for Experimental Biology and Medicine 86, 693-698.

Bechgaard, H. \& Jespersen, S. (1977). Gastrointestinal absorption of niacin in humans. Journal of Pharmaceutical Science 66, 871-872.

Bender, D. A. \& Bender, A. E. (1986). Niacin and tryptophan metabolism: the biochemical basis of niacin requirements and recommendations. Nutrition Abstracts and Reviews $A$ 56, 695-719.

Bendich, A. \& Langseth, L. (1989). Safety of vitamin A. American Journal of Clinical Nutrition 49, 358-371.

Berger, E., Long, E. \& Semenza, G. (1972). The sodium activation of biotin absorption in hamster small intestine in vitro. Biochimica et Biophysica Acta 255, 873-887.

Bergsten, P., Amitai, G., Kehrl, J., Dhariwal, K. R., Klein, H. G. \& Levine, M. (1990). Millimolar concentrations of ascorbic acid in purified human mononuclear leukocytes. Depletion and reaccumulation. Journal of Biological Chemistry 265, 2584-2587.

Bianchi, J., Wilson, F. A. \& Rose, R. C. (1986). Dehydroascorbic acid and ascorbic acid transport systems in the guinea pig ileum. American Journal of Physiology 250, G461-468.

Bitsch, R. \& Schramm, W. (1992). Free and bound vitamin $\mathbf{B}_{6}$ derivatives in plant foods. In Chemical Reactions in Foods. II. (FECS Event No. 174), pp. 285-290.

Bjørneboe, A., Bjørneboe, G-E. A., Bodd, E., Hagen, B. F., Kveseth, N. \& Drevon, C. A. (1986). Transport and distribution of $\alpha$-tocopherol in lymph, serum and liver cells in rats. Biochimica et Biophysica Acta 889, 310-315. 
Bjørneboe, A., Bjørneboe, G-E. A. \& Drevon, C. A. (1990). Absorption, transport and distribution of vitamin E. Journal of Nutrition 120, 233-242.

Bjornsson, T. D., Meffin, P. J., Swezey, S. E. \& Blaschke, T. F. (1979). Effects of clofibrate and warfarin alone and in combination on the disposition of vitamin $\mathrm{K}_{1}$. Journal of Pharmacology \& Experimental Therapeutics $\mathbf{2 1 0}$, 322-326.

Bjornsson, T. D., Meffin, P. J., Swezey, S. E. \& Blaschke, T. F. (1980). Disposition and turnover of vitamin K in man. In Vitamin $K$ Metabolism and Vitamin $K$-dependent Proteins, pp. 328-332 [J. W. Suttie, editor]. Baltimore, Md: University Park.

Blanchard, J. (1991). Effects of gender on vitamin C pharmacokinetics in man. Journal of the American College of Nutrition 10, 453-459.

Blanchard, J., Conrad, K. A., Mead, R. A. \& Garry, P. J. (1990). Vitamin C disposition in young and elderly men. American Journal of Clinical Nutrition 51, 837-845.

Blomstrand, R. \& Forsgren, L. (1968). Vitamin $\mathrm{K}_{1}-{ }^{3} \mathrm{H}$ in man. Its intestinal absorption and transport in the thoracic duct lymph. Internationale Zeitschift für Vitaminforschung 38, 45-64.

Boland, R. L. (1986). Plants as a source of vitamin $\mathrm{D}_{3}$ metabolites. Nutrition Reviews 44, $1-8$.

Bonjour, J. P. (1977). Biotin in man's nutrition and therapy-a review. International Journal for Vitamin and Nutrition Research 47, 107-118.

Bonjour, J. P. (1984). Biotin. In Handbook of Vitamins, Nutritional, Biochemical and Clinical Aspects, pp. $403-435$ [L. J. Machlin, editor]. New York: Dekker.

Bowman, B. B., McCormick, D. B. \& Rosenberg, I. H. (1989). Epithelial transport of water-soluble vitamins. Annual Review of Nutrition 9, $187-199$.

Brody, T., Shane, B. \& Stokstad, E. L. R. (1984). Folic acid. In Handbook of Vitamins, Nutritional, Biochemical and Clinical Aspects, pp. 460-491 [L. J. Machlin, editor]. New York: Dekker.

Brown, E. D., Micozzi, M. S., Craft, N. E., Bieri, J. G., Beecher, G., Edwards, B. K., Rose, A., Taylor, P. R. \& Smith, J. C. (1989). Plasma carotenoids in normal men after a single ingestion of vegetables or purified $\beta$-carotene. American Journal of Clinical Nutrition 49, 1258-1265.

Burton, G. W. (1989). Antioxidant action of carotenoids. Journal of Nutrition 119, 109-111.

Burton, G. W., Ingold, K. U., Foster, D. O., Cheng, S. C., Webb, A., Hughes, L. \& Lusztyk, E. (1988). Comparison of free $\alpha$-tocopherol and $\alpha$-tocopheryl acetate as sources of vitamin $\mathrm{E}$ in rats and humans. Lipids 23, 834-840.

Butterworth, C. E., Newman, A. J. \& Krumdieck, C. L. (1974). Tropical sprue: a consideration of possible etiologic mechanism with emphasis on pteroyl polyglutamate metabolism. Transactions of the American Clinical and Climatological Association 86, 11-22.

Canton, M. C. \& Cremin, F. M. (1990). The effect of dietary zinc depletion and repletion on rats: $\mathrm{Zn}$ concentration in various tissues and activity of pancreatic $\gamma$-glutamyl hydrolase $(E C 3.4 .22 .12)$ as indices of Zn status. British Journal of Nutrition 64, 201-209.

Carter, E. G. A. \& Carpenter, K. J. (1982). The bioavailability for humans of bound niacin from wheat bran. American Journal of Clinical Nutrition 36, 855-861.

Choi, J.-L. \& Rose, R. C. (1989). Transport and metabolism of ascorbic acid in human placenta. American Journal of Physiology 257, C110-113.

Clements, M. R., Davies, M., Fraser, D. R., Lumb, G. A., Mawer, E. B. \& Adams, P. H. (1987). Metabolic inactivation of vitamin $\mathrm{D}$ is enhanced in primary hyperparathyroidism. Clinical Science 73, 659-664.

Clifford, A., Jones, A. D. \& Bills, N. D. (1990). Bioavailability of folates in selected foods incorporated into amino acid-based diets fed to rats. Journal of Nutrition 120, 1640-1647.

Combs, G. F. (1992). Thiamin. In The Vitamins: Fundamental Aspects in Nutrition and Health, pp. 253-268. San Diego, CA: Academic Press.

Coursin, D. B. (1954). Convulsive seizures in infants with pyridoxine-deficient diet. Journal of the American Medical Association 154, 406-408.

Cowan, M. J. (1984). Biotin responsive metabolic disorders in early childhood. In Recent Vitamin Research, pp. 2-23 [M. H. Briggs, editor]. Ohio: CRC Press.

Cowan, M. J., Wara, D. W., Packman, S., Amman, A. J., Yoshino, M., Sweetman, L. \& Nyhan, W. (1979). Multiple biotin-dependent carboxylase deficiencies associated with defects in T-cell and B-cell immunity. Lancet ii, $115-118$.

Craft, N. E. \& Soares, J. H. (1992). Relative solubility, stability, and absorptivity of lutein and $\beta$-carotene in organic solvents. Journal of Agricultural and Food Chemistry 40, 431-434.

Dagnelie, P. C., Vergote, F. J. V. R. A., van Staveren, W. A., van den Berg, H., Dingjan, P. G. \& Hautvast, J. G. A. J. (1990). High prevalence of rickets in infants on macrobiotic diets. American Journal of Clinical Nutrition 51, 202-208.

Dancis, J., Lehanka, J. \& Levitz, M. (1985). Transfer of ribofiavin by the perfused human placenta. Pediatric Research 19, 1143-1146.

Daniel, H., Wille, U. \& Rehner, G. (1983). In vitro kinetics of the intestinal transport of riboflavin in rats. Journal of Nutrition 113, 636-643.

Davies, H. E. F., Davies, J. E. W., Hughes, R. E. \& Jones, E. (1984). Studies on the absorption of L-xyloascorbic acid (vitamin C) in young and elderly subjects. Human Nutrition: Clinical Nutrition 38C, 463-471. 
Davies, M. K., Gregory, M. E. \& Henry, K. M. (1959). The effect of heat on the vitamin $\mathbf{B}_{6}$ of milk. II. A comparison of biological and microbiological tests of evaporated milk. Journal of Dairy Research 26, 215-220.

Davis, R. E. \& Icke, G. C. (1983). Clinical chemistry of thiamin. Advances in Clinical Chemistry 23, 93-140.

Deluca, H. F. (1988). The vitamin D story: a collaborative effort of basic science and clinical medicine. $F A S E B$ Journal 2, 224-236.

Deutsche Gesellschaft für Ernährung (1988). Erganzungsband zum Ernährungsbericht 1988. Frankfurt: DGE.

Drevon, C. A. (1991). Absorption, transport and metabolism of vitamin E. Free Radical Research Communications 14, 229-246.

Dutta, P., Pinto, J. \& Rivlin, R. (1985). Antimalarial effects of riboflavin deficiency. Lancet ii, 1040-1043.

Evans, W. B. \& Wollaeger, E. E. (1966). Incidence and severity of nutritional deficiency states in chronic exocrine pancreatic insufficiency: comparison with non-tropical sprue. American Journal of Digestive Diseases 11, 594-606.

FAO/WHO. (1967). Requirements of vitamin A, thiamine, riboflavine and niacin, pp. 271-276. Rome: FAO (FAO Nutrition Meetings Report Series no. 41; WHO Technical Report Series no. 362).

FAO/WHO (1988). Requirements of vitamin A, iron, folate and vitamin $B_{12}$, pp. 17-18, 29-30. Rome: FAO ( $F A O$ Food and Nutrition Series no. 23).

Ferland, G., Sadowski, J. A. \& O'Brien, M. E. (1993). Dietary induced subclinical vitamin K deficiency in normal human subjects. Journal of Clinical Investigation 91, 1761-1768.

Food and Nutrition Board (1989). Recommended Dietary Allowances, 10th Edn, pp. 169-173. Washington, DC: National Academy of Sciences.

Ford, J. E., Salter, D. N. \& Scott, K. J. (1969). The folate-binding protein in milk. Journal of Dairy Research 36, 435-446.

Foss, Z. M. S. (1981). Thesis, University of Nebraska, Lincoln, Nebraska, USA.

Fraser, D. R. (1983). The physiological economy of vitamin D. Lancet i, 969-972.

Friedrich, W. (1987). Handbuch der Vitamine, pp. 305-308. Munich: Urban \& Schwarzenberg.

Fukui, E., Kurohara, H., Kageyu, A., Kurosaki, Y., Nakayama, T. \& Kimura, T. (1989). Enhancing effect of medium-chain tryglycerides on intestinal absorption of $d$ - $\alpha$-tocopherol acetate from lecithin-dispersed preparations in the rat. Journal of Pharmacobio-Dynamics 12, 80-86.

Gallo-Torres, H. E. (1980). Absorption, transport and metabolism. In Vitamin E: a Comprehensive Treatise, pp. $170-267$ [L. J. Machlin, editor]. New York: Dekker.

Gascon-Barré, M. (1986). Is there any physiological significance to the enterohepatic circulation of vitamin D sterols. Journal of the American College of Nutrition 5, 317-324.

Ghitis, J. (1967). The folate binding in milk. American Journal of Clinical Nutrition 20, 1-4.

Gilbert, J. A. \& Gregory, J. F. (1992). Pyridoxine-5'- $\beta$-D-glucoside affects the metabolic utilization of pyridoxine in rats. Journal of Nutrition 122, 1029-1035.

Goodman, D. S., Blomstrand, R., Werner, B., Huang, H. S. \& Shiratori, T. (1966). The intestinal absorption and metabolism of vitamin $A$ and $\beta$-carotene in man. Journal of Clinical Investigation 45, 1615-1623.

Goodman, D. S. \& Huang, H. S. (1965). Biosynthesis of vitamin A with rat intestinal enzymes. Science 149, $879-880$

Gravel, R. A., Lam, K. F., Mahuran, D. \& Kronis, A. (1980). Purification of human liver propionyl-CoA carboxylase by carbon tetrachloride extraction and monomeric avidin affinity chromatography. Archives of Biochemistry and Biophysics 201, 669-673.

Greer, F. R., Mummah-Schendel, L. L., Marshall, S. \& Suttie, J. W. (1988). Vitamin K, (phylloquinone) and vitamin $\mathrm{K}_{2}$ (menaquinone) status in newborns during the first week of life. Pediatrics 81, 137-140.

Gregory, J. F. (1980). Effect of $\epsilon$-pyridoxyllysine bound to dietary protein on the vitamin $\mathbf{B}_{6}$ status of rats. Journal of Nutrition 110, 995-1005.

Gregory, J. F., Bhandari, S. D., Bailey, L. B., Toth, J. P., Baumgartner, T. G. \& Cerda, J. J. (1991 a). Relative bioavailability of deuterium-labelled monoglutamyl and hexaglutamyl folates in human subjects. American Journal of Clinical Nutrition 53, 736-740.

Gregory, J. F. \& Ink, S. L. (1987). Identification and quantification of pyridoxine- $\beta$-glucoside as a major form of vitamin $\mathrm{B}_{6}$ in plant-derived foods. Journal of Agricultural and Food Chemistry 35, 76-82.

Gregory, J. F. \& Kirk, J. R. (1977). Interaction of pyridoxal and pyridoxal phosphate with peptides in a model food system during thermal processing. Journal of Food Science 42, 1554-1557, 1561.

Gregory, J. F., Trumbo, P. R., Bailey, L. B., Toth, J. P., Baumgartner, T. G. \& Cerda, J. J. (1991 b). Bioavailability of pyridoxine-5- $\beta$-D-glucoside determined in humans by stable-isotope methods. Journal of Nutrition 121, $177-186$.

Gronowska-Senger, A. \& Wolf, G. (1970). Effect of dietary protein on the enzyme from rat and human intestine which converts $\beta$-carotene to retinal. Journal of Nutrition 100, 300-308.

Gubler, C. J. (1991). Thiamin. In Handbook of Vitamins, Nutritional, Biochemical and Clinical Aspects, pp. 233-281 [L. J. Machlin, editor]. New York: Dekker.

Guillaumont, M., Sann, L., Leclerq, M., Dostalova, L., Vignal, B. \& Frederich, A. (1993). Changes in hepatic vitamin $\mathrm{K}_{1}$ levels after prophylactic administration to the newborn. Journal of Pediatric Gastroenterology and Nutrition 16, 10-14.

Halstead, C. (1990). Intestinal absorption of dietary folates. In Folic Acid Metabolism in Health and Disease, pp. 23-45 [M. F. Picciano, E. L. R. Stokstad \& J. F. Gregory, editors] New York: Wiley-Liss. 


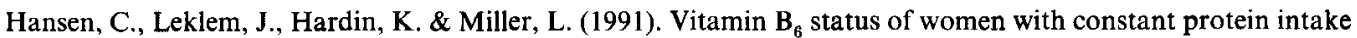
and four levels of vitamin $B_{6}$. FASEB Journal 5, 556A.

Hathcock, J. N. (1985). Quantitative evaluation of vitamin safety. Pharmacy Times May, 104-113.

Heinrich, H. C. \& Gabbe, E. E. (1990). Experimental basis of oral and parenteral therapy with cyano- or aquacobalamin. Biomedicine and Physiology of Vitamin $B_{12}$. London: Children's Medical Charity.

Heinrich, H. C. \& Wolfsteller, E. (1966). [High dosage oral vitamin $\mathbf{B}_{12}$ therapy. Experimental basis and practical application.] MedizinischeKlinik 61, 756-763.

Heldenberg, D., Tenenbaum, G. \& Weisman, Y. (1992). Effect of iron on serum 25-hydroxyvitamin D and 24,25dihydroxyvitamin D concentrations. American Journal of Clinical Nutrition 56, 533-536.

Henderson, C. T., Mobarhan, S., Bowen, P., Stacewicz-Sapuntzakis, M., Langenberg, P., Kiani, R., Lucchesi, D. \& Sugerman, S. (1989). Normal serum response to oral beta-carotene in humans. Journal of the American College of Nutrition 8, 625-635.

Henderson, L. M. (1983). Niacin. Annual Review of Nutrition 3, 289-307.

Herbert, V. (1988). Vitamin $\mathbf{B}_{12}$ : plant sources, requirements, and assay. American Journal of Clinical Nutrition 48, 852-858.

Herzlich, B. \& Herbert, V. (1984). The role of the pancreas in cobalamin (vitamin B $_{12}$ ) absorption. American Journal of Gastroenterology 79, 489-493.

Heymann, W. (1936). Absorption of carotene. American Journal of Diseases of Children 51, 273-283.

Hodges, R. E., Ohlson, M. A. \& Bean, W. B. (1958). Pantothenic acid deficiency in man. Journal of Clinical Investigation 37, 1642-1657.

Hollander, D. E. (1973). Vitamin $\mathrm{K}_{1}$ absorption by everted intestinal sacs of the rat. American Journal of Physiology 225, 360-364.

Hollander, D. E. (1981). Intestinal absorption of vitamins A, E, D, and K. Journal of Laboratory and Clinical Medicine $97,449-462$.

Hollander, D. E. \& Dadufalza, V. (1989). Lymphatic and portal absorption of vitamin E in aging rats. Digestive Diseases and Sciences 34, 768-772.

Hollander, D. E., Rim, E. \& Ruble, P. E. (1977). Vitamin $K_{2}$ colonic and ileal in vivo absorption: bile, fatty acids, and $\mathrm{pH}$ effects on transport. American Journal of Physiology 233, E124-129.

Hollander, D. E. \& Ruble, P. E. (1978). $\beta$-Carotene intestinal absorption: bile, fatty acid, pH, and flow rate effects on transport. American Journal of Physiology 235, E686-691.

Hollis, B. W., Roos, B. A., Draper, H. H. \& Lambert, P. W. (1981 a). Vitamin D and its metabolites in human and bovine milk. Journal of Nutrition 111, 1240-1248.

Hollis, B. W., Roos, B. A., Draper, H. H. \& Lambert, P. W. (1981 b). Occurrence of vitamin D sulfate in human milk whey. Vitamin D and its metabolites in human and bovine milk. Journal of Nutrition 111, 384-390.

Holmberg, I., Aksnes, L., Berlin, T., Lindback, B., Zemgals, J. \& Lindeke, B. (1990). Absorption of a pharmacological dose of vitamin $\mathrm{D}_{3}$ from two different lipid vehicles in man: comparison of peanut oil and a medium chain triglyceride. Biopharmaceutics and Drug Deposition 11, 807-815.

Hoppner, K. \& Lampi, B. (1986). Bioavailability of food folacin as determined by rat liver bioassay. Nutrition Reports International 34, 489-494.

Hornig, D. (1975). Distribution of ascorbic acid, metabolites and analogues in man and animals. Annals of the New York Academy of Sciences 258, 103-118.

Hornig, D. (1981). Metabolism and requirements of ascorbic acid in man. South African Medical Journal 60 , $818-823$.

Hornig, D., Vuilleumier, J-P. \& Hartmann, D. (1980). Absorption of large, single, oral intakes of ascorbic acid. International Journal for Vitamin and Nutrition Research 50, 309-314.

Horst, R. L., Goff, J. P. \& Reinhardt, T. A. (1990). Advancing age results in reduction of intestinal and bone 1,25dihydroxyvitamin D receptor. Endocrinology 126, 1053-1057.

Horwitt, M. K., Harper, A. E. \& Henderson, L. M. (1981). Niacin-tryptophan relationships for evaluating niacin equivalents. American Journal of Clinical Nutrition 34, 423-427.

Howard, L., Wagner, C. \& Schenker, S. (1974). Malabsorption of thiamin in folate-deficient rats. Journal of Nutrition 104, $1024-1032$.

Hoyumpa, A. M. (1982). Characterization of normal intestinal thiamin transport in animals and man. Annals of the New York Academy of Sciences 378, 337-343.

Hoyumpa, A. M., Middleton, H. M., Wilson, F. A. \& Schenker, S. (1975). Thiamin transport across the rat intestine. I. Normal characteristics. Gastroenterology 68, 1218-1227.

Hoyumpa, A. M., Strickland, R., Sheehan, J. J., Yarborough, G. \& Nichols, S. (1982). Dual system of intestinal thiamine transport in humans. Journal of Laboratory and Clinical Medicine 99, 701-708.

Hume, E. M. \& Krebs, H. A. (1949). Vitamin A Requirements of Human Adults (Special Report Series no. 264). London: Medical Research Council.

Ingold, K. U., Burton, G. W., Foster, D. O. \& Hughes, L. (1990). Further studies of a new vitamin E analogue more active than $\alpha$-tocopherol in the rat curative myopathy bioassay. FEBS Letters 267, 63-65.

Ingold, K. U., Burton, G. W., Foster, D. O., Hughes, L., Lindsay, D. A. \& Webb, A. (1987). Biokinetics of and discrimination between dietary $R R R$ - and $S R R$ - $\alpha$-tocopherols in the male rat. Lipids 22, 163-172.

James, D. R., Owen, G., Campbell, I. A. \& Goodchild, M. C. (1992). Vitamin A absorption in cystic fibrosis: risk of hypervitaminosis A. Gut 33, 707-710. 
Jensen, C. D., Howes, T. W., Spiller, G. A., Pattison, T. S., Whittam, J. H. \& Scala, J. (1987). Observations on the effects of ingesting cis- and trans-beta-carotene isomers on human serum concentrations. Nutrition Reports International 35, 413-442.

Johnson, E. J. \& Russell, R. M. (1992). Distribution of orally administered $\beta$-carotene among lipoproteins in healthy men. American Journal of Clinical Nutrition 56, 128-135.

Jolly, D. W., Craig, C. \& Nelson, T. E. (1977). Estrogen and prothrombin synthesis; effect of estrogen on absorption of vitamin K. American Journal of Physiology 232, H12-17.

Jusko, W. J. \& Levy, G. (1975). Absorption, protein binding and elimination of riboflavin. In Riboflavin, pp. 99-152 [R. S. Rivlin, editor]. New York: Plenum Press.

Kabir, H., Leklem, J. E. \& Miller, L. T. (1983). Relationship of the glycosylated vitamin B $_{6}$ content of foods to vitamin $\mathbf{B}_{6}$ bioavailability in humans. Nutrition Reports International 28, 709-716.

Kahlon, T. S., Chow, F. I., Hoefer, J. L. \& Betschart, A. A. (1986). Bioavailability of vitamins A and E as influenced by wheat bran and bran particle size. Cereal Chemistry 63, 490-493.

Kallner, A., Hartmann, D. \& Hornig, D. (1977). On the absorption of ascorbic acid in man. International Journal for Vitamin and Nutrition Research 47, 383-388.

Kanazawa, S. \& Herbert, V. (1982). Vitamin $B_{12}$ analogue content in human red cells, liver and brain. Clinical Research 30, 504A.

Kaplan, L. A., Lau, J. M. \& Stein, E. A. (1990). Carotenoid composition, concentrations and relationships in various human organs. Clinical Physiology and Biochemistry 8, 1-10.

Kasparek, S. (1980). Chemistry of tocopherols and tocotrienols. In Vitamin E: A Comprehensive Treatise, pp. 7-65 [L. J. Machlin, editor]. New York: Dekker.

Kato, S. (1959). The effect of nicotine on thiamin levels in the chick. Folia Pharmacologica Japonica 55, 5-12.

Keagy, P. M., Shane, B. \& Oace, S. M. (1988). Folate bioavailability in humans: effects of wheat bran and beans. American Journal of Clinical Nutrition 47, 80-88.

Kern, F., Birkner, H. J. \& Ostrower, V. S. (1978). Binding of bile acids by dietary fiber. American Journal of Clinical Nutrition 31, S175-179.

Kies, C., Wishart, C., McGee, M., Foss, Z., Yong, L. C., Quillian, J. \& Fox, H. M. (1982). Pantothenic acid levels in urine, blood serum, and whole blood of adult humans fed graded levels of pantothenic acid. Federation Proceedings 41, 276A.

Kimura, M. \& Itokawa, Y. (1977). Effects of calcium and magnesium deficiency on thiamine distribution in rat brain and liver. Journal of Neurochemistry 28, 389-393

Lakshmi, A. V. \& Bamji, M.S. (1979). Metabolism of $\left[2-{ }^{14}\right.$ C]pyridoxine in riboflavin deficiency. Biochemical Medicine 22, 274-281.

Lala, V. R. \& Reddy, V. (1970). Absorption of $\beta$-carotene from green leafy vegetables in undernourished children. American Journal of Clinical Nutrition 23, 110-113.

Lane, P. A. \& Hathaway, W. E. (1985). Vitamin K in infancy. Journal of Pediatrics 106, 351-359.

Lawson, D. E. M. (1980). Metabolism of vitamin D. In Vitamin D: Molecular Biology and Clinical Nutrition [A. W. Norman, editor]. New York: Dekker.

Lin, M. M. S. (1981). Thesis. University of Nebraska, Lincoln, Nebraska, USA.

Linnell, J. C., Smith, A. D. M., Smith, C. L., Wilson, J. \& Matthews, D. M. (1968). Effects of smoking on metabolism and excretion of vitamin $\mathbf{B}_{12}$. British Medical Journal ii, 215-216.

Loew, D. (1991). [Pharmacokinetics of the cobalamins: cyano-, hydroxy-, methylcobalamin.] In Pharmakologie und klinische Anwendung hochdosierter B-Vitamine [N. Reitbrock, editor], Darmstadt.

Loew, D. et al. (1988). [Pharmacokinetics of hydroxycobalamin and folic acid.] Vitaminspur 3, 168-172.

Lubin, R., Daum, K. A. \& Bean, W. B. (1956). Studies of pantothenic acid metabolism. American Journal of Clinical Nutrition 4, 420-430.

McCormick, D. B. (1972). The fate of riboflavin in the mammal. Nutrition Reviews 30, 75-79.

McCormick, D. B. (1989). Two interconnected B vitamins: riboflavin and pyridoxine. Physiological Reviews 69 , 1170-1198.

Machlin, L. J. (1984). Pantothenic acid. In Handbook of Vitamins, Nutritional, Biochemical and Clincial Aspects, pp. 437-457 [L. J. Machlin, editor]. New York: Dekker.

McLaren, D. S. \& Zekian, B. (1971). Failure of enzymic cleavage of $\beta$-carotene. American Journal of Diseases of Children 121, 278-280.

Maiani, G., Mobarhan, S., Ceccanti, M., Ranaldi, L., Gettner, S., Bowen, P., Friedman, H., de Lorenzo, A. \& Ferro-Luzzi, A. (1989). Beta-carotene serum response in young and elderly females. European Journal of Clinical Nutrition 43, 749-761.

Maislos, M., Silver, J. \& Fainaru, M. (1981). Intestinal absorption of vitamin D sterols: differential absorption into lymph and portal blood in the rat. Gastroenterology 80, 1528-1534.

Marquet, A. (1977). New aspects of the chemistry of biotin and of some analogs. Pure and Applied Chemistry 49, 183-196.

Mason, J. B., Gibson, N. \& Kodicek, E. (1973). The chemical nature of the bound nicotinic acid of wheat bran: studies of nicotinic acid-containing macromolecules. British Journal of Nutrition 30, 297-311.

Matsuda, I., Endo, F. \& Motohara, K. (1991). Vitamin K deficiency in infancy. World Review of Nutrition and Dietetics 64, 85-108. 
Matsuura, A., Iwashima, A. \& Nose, Y. (1975). Purification of thiamine-binding protein from Escherichia coli by affinity chromatography. Biochemical and Biophysical Research Communications 51, 241-246.

Matthews, D. M. (1974). Absorption of water-soluble vitamins. In Biomembranes: Intestinal Absorption, vol. 4B, pp. 847-915 [D. H. Smyth, editor]. New York: Plenum Press.

Mawer, E. B., Backhouse, J., Holman, C. A., Lumb, G. A. \& Stanbury, S. W. (1972). The distribution and storage of vitamin D and its metabolites in human tissues. Clinical Science 43, 413-431.

Mayersohn, M., Feldman, S. \& Gibaldi, M. (1969). Bile salt enhancement of riboflavin and flavin mononucleotide absorption in man. Journal of Nutrition 98, 288-296.

Melethil, S., Mason, W. D. \& Chang, C.-J. (1986). Dose-dependent absorption and excretion of vitamin C in humans. International Journal of Pharmaceutics 31, 83-90.

Merrill, A. H. \& Henderson, J. M. (1987). Diseases associated with defects in vitamin $B_{6}$ metabolism or utilization. Annual Review of Nutrition 7, 137-156.

Micozzi, M. S., Brown, E. D., Edwards, B. K., Bieri, J. G., Taylor, P. R., Khachik, F., Beecher, G. R. \& Smith, J. C. (1992). Plasma carotenoid response to chronic intake of selected foods and $\beta$-carotene supplements in men. American Journal of Clinical Nutrition 55, 1120-1125.

Mills, C. A., Cottingham, E. \& Taylor, E. (1976). The effect of advancing age on dietary thiamine requirements. Archives of Biochemistry 9, 221-227.

Monk, B. E., (1982). Metabolic carotenaemia. British Journal of Dermatology 106, 485-487.

Mrochek, J. E., Jolley, R. L., Young, D. S. \& Turner, W. J. (1976). Metabolic response of humans to ingestion of nicotinic acid and nicotinamide. Clinical Chemistry 22, 1821-1827.

Munnich, A., Ogier, H. \& Saudubray, J-M. (1990). [Pantothenic acid.] In Le Vitamine: Aspetti Metabolici, Genetici, Nutrizionali e Terapeutici, pp. 185-201. Rome: Masson.

Munnich, A., Saudubray, J. M., Carré, G., Coudé, F. X., Ogier, H., Charpentier, C. \& Frézal, J. (1981). Defective biotin absorption in multiple carboxylase deficiency. Lancet ii, 263.

Murata, A. (1991). Smoking and vitamin C. World Review of Nutrition and Dietetics 64, 31-57.

Murata, K. (1965). Review of Japanese literature on beriberi and thiamin, p. 220. Tokyo: Vitamin B1 Research Committee of Japan.

Murty, C. V. R. \& Adiga, P. R. (1982). Pregnancy suppression by active immunization against gestation-specific riboflavin carrier protein. Science 216, 191-193.

National Research Council (1989). Recommended Dietary Allowances, 10th Edn, pp. 137-142. Washington, DC: National Academy Press.

Need, G. N., Morris, H. A., Horowitz, M. Y. \& Nordin, B. E. C. (1993). Effects of skin thickness, age, body fat, and sunlight on serum 25-hydroxyvitamin D. American Journal of Clinical Nutrition 58, 882-885.

Nishino, K. \& Itokawa, Y. (1977). Thiamin malabsorption in vitamin $\mathbf{B}_{6}$ or vitamin $\mathbf{B}_{12}$ deficient rats. Journal of Nutrition 107, 775-782.

Nose, Y. \& Iwashima, A. (1965). Intestinal absorption of thiamin propyl disulfide. Journal of Vitaminology 11, $165-170$.

Olson, J. A. (1987). Recommended Dietary Intakes (RDI) of vitamin K in humans. American Journal of Clinical Nutrition 45, 687-692.

Olson, J. A. \& Hayaishi, O. (1965). The enzymatic cleavage of $\beta$-carotene into vitamin A by soluble enzymes of rat liver and intestine. Proceedings of the National Academy of Sciences, USA 54, 1364-1370.

Omaye, S. T. \& Chow, F. I. (1984). Effect of hard red spring wheat bran on the bioavailability of lipid-soluble vitamins and growth of rats fed for 56 days. Journal of Food Science 49, $504-506$.

Parker, R. S., Viereck, S. M., Spielman, A. B., Brenna, J. T. \& Goodman, K. J. (1992). Metabolism and biokinetics of ${ }^{13} \mathrm{C}$ - $\beta$-carotene in humans following a small oral dose. FASEB Journal 6, 1645A.

Patterson, L. T., Nahrwold, D. L. \& Rose, R. C. (1982). Ascorbic acid uptake in guinea pig intestinal mucosa. Life Sciences 31, 2783-2791

Pearson, W. N. (1967). Blood and urinary vitamin levels as potential indices of body stores. American Journal of Clinical Nutrition 20, 514-525.

Pietrzik, K. (1993). Problems of folate bioavailability. In Nutritional, Chemical and Food Processing Implications of Nutrient Availability. Proceedings, Part 2, 'Bioavailability 93', pp. 289-299 [U. Schlemmer, editor].

Pike, R. L. \& Brown, M. L. (1975). Water-soluble vitamins. Nutrition: an Integrated Approach, $2 \mathrm{nd}$ edn, pp. 80-139. New York: Wiley.

Pinto, J., Huang, Y. P. \& Rivlin, R. S. (1981). Inhibition of riboflavin metabolism in rat tissues by chlorpromazine, imipramine and amitriptyline. Journal of Clinical Investigation 67, 1500-1506.

Prentice, A. M. \& Bates, C. J. (1980). Refection in rats fed on a sucrose-based riboflavin-deficient diet. British Journal of Nutrition 43, 171-177.

Prince, M. R., Frisoli, J. K., Goetschkes, M. M., Stringham, J. M. \& LaMuraglia, G. M. (1991). Rapid serum carotene loading with high-dose $\beta$-carotene: clinical implications. Journal of Cardiovascular Pharmacology 17, 343-347.

Rafsky, H. A., Newman, B. \& Jolliffe, N. (1947). The relationship of gastric acidity to thiamine excretion in the aged. Journal of Laboratory and Clinical Medicine 32, 118-123.

Reibel, D. K., Wyse, B. W., Berkich, D. A., Palko, W. M. \& Neely, J. R. (1981). Effects of diabetes and fasting on pantothenic acid metabolism in rats. American Journal of Physiology 240, E597-601. 
Reisenauer, A. M., Krumdieck, C. L. \& Halstead, C. H. (1977). Folate conjugase: two separate activities in human jejunum. Science 198, 196-197.

Reynolds, R. D. (1988). Bioavailability of vitamin $B_{6}$ from plant foods. American Journal of Clinical Nutrition 48 , 863-867.

Rhode, B. M., Cooper, B. A. \& Farmer, F. A. (1983). Effect of orange juice, folic acid, and oral contraceptives on serum folate in women taking a folate-restricted diet. Journal of the American College of Nutrition 2,221-230.

Rietz, P., Gloor, U. \& Wiss, O. (1970). [Menaquinones from human liver and sewage sludge.] Internationale Zeitschrift für Vitaminforschung 40, 351-362.

Ristow, K. A., Gregory, J. F. \& Damron, B. L. (1982). Effect of dietary fiber on the bioavailability of folic acid monoglutamate. Journal of Nutrition 112, 750-758.

Rivers, J. M. (1987). Safety of high-level vitamin C ingestion. Annals of the New York Academy of Sciences 498, 445-453.

Rock, C. L. \& Swendseid, M. E. (1992). Plasma $\beta$-carotene response in humans after meals supplemented with dietary pectin. American Journal of Clinical Nutrition 55, 96-99.

Rose, R. C. (1988). Transport of ascorbic acid and other water-soluble vitamins. Biochimica et Biophysica Acta 947, 335-366.

Russell, R. M., Dahr, G. J., Dutta, S. K. \& Rosenberg, I. H. (1979). Influence of intraluminal pH on folate absorption. Studies in control subjects and in patients with pancreatic insufficiency. Journal of Laboratory and Clinical Medicine 93, 428-436.

Sadoogh-Abasian, F. \& Evered, D. F. (1980). Absorption of nicotinic acid and nicotinamide from rat small intestine in vitro. Biochimica et Biophysica Acta 598, 385-391.

Sadowski, J., Bacon, D., Hood, S., Davidson, K., Gauter, C., Haroon, Y. \& Shepard, D. (1988). The application of methods used for the evaluation of vitamin $\mathrm{K}$ nutritional status in human and animal studies. In Current Advances in Vitamin K Research, pp. 453-463 [J. W. Suttie, editor]. Amsterdam: Elsevier Science Publishing Co.

Said, H. M. \& Hollander, D. (1985). Does aging affect the intestinal transport of riboflavin? Life Sciences 36, 69-73.

Said, H. M., Hollander, D. \& Duong, Y. (1985). A dual, concentration-dependent transport system for riboflavin in rat intestine in vitro. Nutrition Research 5, 1269-1279.

Said, H. M., Horne, D. W. \& Wagner, C. (1986). Effect of human milk folate binding protein on folate intestinal transport. Archives of Biochemistry and Biophysics 251, 114-120.

Said, H. M., Ong, D. E. \& Shingleton, J. L. (1989). Intestinal uptake of retinol: enhancement by bovine milk $\beta$-lactoglobulin. American Journal of Clinical Nutrition 49, 690-694.

Said, H. M., Redha, R. \& Nylander, W. (1987). A carrier-mediated, Na + gradient-dependent transport for biotin in human intestinal brush-border membrane vesicles. American Journal of Physiology 253, G631-636.

Salter, D. N. \& Blakeborough, P. (1988). Influence of goat's milk folate-binding protein on transport of 5-methyltetrahydrofolate in neonatal goat small intestinal brush border membrane vesicles. British Journal of Nutrition 59, 497-507.

Sampson, D. A. \& Chung, S. (1991). Dietary protein quality and vitamin $\mathbf{B}_{6}$ nutritional status in lactating rats. FASEB Journal 5, 557A.

Satyanarayana, U. \& Narasinga Rao, B. S. (1980). Dietary tryptophan level and the enzymes of tryptophan NAD pathway. British Journal of Nutrition 43, 107-113.

Sauberlich, H. E., Hodges, R. E., Wallace, D. L., Kolder, H., Canham, J. E., Hood, J., Raica, N. \& Lowry, L. K. (1974). Vitamin A metabolism and requirements in the human studied with the use of labeled retinol. Vitamins and Hormones 32, 251-275.

Saupe, J., Shearer, M. J. \& Kohlmeier, M. (1994). Phylloquinone (vitamin $\mathbf{K}_{1}$ ) transport and its' influence on gamma-carboxyglutamic (Gla)-residues of osteocalcin in patients on maintenance hemodialysis. American Journal of Clinical Nutrition (In the press.)

Schaller, K. \& Höller, H. (1974). Thiamine absorption in the rat. 1. Intestinal permeability and active transport of thiamine; passage and cleavage of thiamine pyrophosphate in vitro. International Journal for Vitamin and Nutrition Research 44, 443-451.

Schaus, E. E., de Lumen, B. O., Chow, F. I., Reyes, P. \& Omaye, S. T. (1985). Bioavailability of vitamin E in rats fed graded levels of pectin. Journal of Nutrition 115, 263-270.

Schorah, C. J. (1992). The transport of vitamin C and effects of disease. Proceedings of the Nutrition Society 51, 189-198.

Schubiger, G., Tonz, O., Gruter, J. \& Shearer, M. J. (1993). Vitamin K$_{1}$ concentration in breast-fed neonates after oral or intramuscular administration of a single dose of a new mixed micellar preparation of phylloquinone. Journal of Pediatric Gastroenterology and Nutrition 16, 435-439.

Selhub, J., Powell, G. M. \& Rosenberg, I. H. (1984). Intestinal transport of 5-methyltetrahydrofolate. American Journal of Physiology 246, G515-520.

Shaw, S., Meyers, S., Colman, N., Jayatilleke, E. \& Herbert, V. (1987). The ileum is the major site of absorption of vitamin $\mathrm{B}_{12}$. Federation Proceedings 46, 1004A.

Shearer, M. J. (1990). Vitamin K and vitamin K-dependent proteins. British Journal of Haematology 75, $156-162$.

Shearer, M. J., Barkhan, P.\& Webster, G. R. (1970). Absorption and excretion of an oral dose of tritiated vitamin $\mathrm{K}_{1}$ in man. British Journal of Haematology 18, 297-308. 
Shearer, M. J., McBurney, A. \& Barkhan, P. (1974). Studies on the absorption and metabolism of phylloquinone (vitamin $\mathrm{K}_{1}$ ) in man. Vitamins and Hormones 32, 513-542.

Shearer, M. J., Rahim, S., Barkhan, P. \& Stimmer, L. (1982). Plasma vitamin $K_{1}$ in mothers and their newborn babies. Lancet ii, $460-463$.

Shinzawa, T., Mura, T., Tsunei, M. \& Shiraki, K. (1989). Vitamin K absorption capacity and its association with vitamin $\mathrm{K}$ deficiency. American Journal of Diseases of Children 143, 686-689.

Simpson, K. L. \& Chichester, C. O. (1981). Metabolism and nutritional significance of carotenoids. Annual Review of Nutrition 1, 351-374.

Sitrin, M. D. \& Bengoa, J. M. (1987). Intestinal absorption of cholecalciferol and 25-hydroxycholecalciferol in chronic cholestatic liver disease. American Journal of Clinical Nutrition 46, 1011-1015.

Somogyi, J. C. (1971). On antithiamine factors of fern. Journal of Vitaminology 17, 165-174.

Spector, R. \& Boose, B. (1979). Active transport of riboflavin by the isolated choroid plexus in vitro. Journal of Biological Chemistry 254, 10286-10289.

Spector, R. \& Boose, B. (1982). Riboflavin transport by rabbit kidney slices: characterization and relation to cyclic organic acid transport. Journal of Pharmacology and Experimental Therapeutics 221, 394-398.

Spencer, R. P. \& Brody, K. R. (1964). Biotin transport by small intestine of rat, hamster, and other species. American Journal of Physiology 206, 653-657.

Stahl, W., Schwarz, W., Sundquist, A. R. \& Sies, H. (1992). cis-trans Isomers of lycopene and $\beta$-carotene in human serum and tissues. Archives of Biochemistry and Biophysics 294, 173-177.

Stamp, T. C. B. (1975). Factors in human vitamin D nutrition and in the production and cure of classical rickets. Proceedings of the Nutrition Society 34, 119-130.

Steinberg, S. E., Campbell, C. L. \& Hillman, R. S. (1979). Kinetics of the normal folate enterohepatic cycle. Journal of Clinical Investigation 64, 83-88.

Stenflo, J., Fernlund, P., Egan, W. \& Roepstorff, P. (1974). Vitamin K dependent modifications of glutamic acid residues in prothrombin. Proceedings of the National Academy of Sciences, USA 71, 2730-2733.

Stevenson, N. R. (1974). Active transport of L-ascorbic acid in the human ileum. Gastroenterology 67, 952-956.

Strauss, L. H. \& Scheer, P. (1939). [Effect of nicotine on vitamin C metabolism.] Zeitschrift für Vitaminforschung 9, 39-48.

Sugarman, B. \& Munro, H. N. (1980). $\left[{ }^{14}\right.$ C]pantothenate accumulation by isolated adipocytes from adult rats of different ages. Journal of Nutrition 110, 2297-2301.

Suttie, J. W. (1984). Vitamin K. In Handbook of Vitamins, Nutritional, Biochemical and Clinical Aspects, pp. 147-198 [L. J. Machlin, editor]. New York: Dekker.

Suttie, J. W., Mummah-Schendel, L. L., Shah, D. V., Lyle, B. J. \& Greger, J. L. (1988). Vitamin K deficiency from dietary vitamin $\mathrm{K}$ restriction in humans. American Journal of Clinical Nutrition 47, 475-480.

Sweetman, L., Surh, L., Baker, H., Peterson, R. M. \& Nyhan, W. L. (1981). Clinical and metabolic abnormalities in a boy with dietary deficiency of biotin. Pediatrics 68, 553-558.

Tadera, K., Arima, M., Yoshino, S., Yagi, F. \& Kobayashi, A. (1986). Conversion of pyridoxine into 6-hydroxypyridoxine by food components, especially ascorbic acid. Journal of Nutritional Science and Vitaminology 32, 267-277.

Tadera, K., Kaneko, T. \& Yagi, F. (1988). Isolation and structural elucidation of three new pyridoxine-glycosides in rice bran. Journal of Nutritional Science and Vitaminology 34, 167-177.

Tamura, T. \& Stokstad, E. L. R. (1973). The availability of food folate in man. British Journal of Haematology 25, 513-532.

Tanaka, Y., Frank, H. \& DeLuca, H. F. (1973). Biological activity of 1,25-dihydroxyvitamin $D_{3}$ in the rat. Endocrinology 92, 417-422.

Tarr, J. B., Tamura, T. \& Stokstad, E. L. R. (1981). Availability of vitamin B $_{6}$ and pantothenate in an average American diet in man. American Journal of Clinical Nutrition 34, 1328-1337.

Thoene, J. \& Wolf, B. (1983). Biotinidase deficiency in juvenile multiple carboxylase deficiency. Lancet ii, 398.

Toggenburger, G., Landoldt, M. \& Semenza, G. (1979). $\mathrm{Na}^{+}$-dependent electroneutral L-ascorbate transport across brush border membrane vesicles from human small intestine. Inhibition by D-erythorbate. FEBS Letters $108,473-476$.

Traber, M. G., Burton, G. W., Ingold, K. U. \& Kayden, H. J. (1990). $R R R$ - and $S R R$ - $\alpha$-tocopherols are secreted without discrimination in human chylomicrons, but $R R R$ - $\alpha$-tocopherol is preferentially secreted in very low density lipoproteins. Journal of Lipid Research 31, 675-685.

Traber, M. G., Ingold, K. U., Burton, G. W. \& Kayden, H. J. (1988). Absorption and transport of deuteriumsubstituted $2 R, 4^{\prime} R, 8^{\prime} R$ - $\alpha$-tocopherol in human lipoproteins. Lipids 23, 791-797.

Traber, M. G. \& Kayden, H. J. (1989). Preferential incorporation of $\alpha$-tocopherol vs $\gamma$-tocopherol in human lipoproteins. American Journal of Clinical Nutrition 49, 517-526.

Traber, M. G., Kayden, H. J., Balmer Green, J. \& Green, M. H. (1986). Absorption of water-miscible forms of vitamin $\mathrm{E}$ in a patient with cholestasis and in thoracic duct-cannulated rats. American Journal of Clinical Nutrition 44, 914-923.

Trumbo, P. R. (1991). Influence of dietary protein on vitamin $\mathrm{B}_{6}$ bioavailability and secretion in milk. $F A S E B$ Journal 5, 557A.

van den Berg, H. (1991). Modern Lifestyles, Lower Energy Intake and Micronutrient Status, pp. 21-36. Berlin: Springer-Verlag. 
van den Berg, H. (1993). General aspects of bioavailability of vitamins. In: Proceedings Bioavailability '93; Nutritional, chemical and food processing in implications of nutrient availability. Berichte der Bundesforschunganstalt für Ernährung, pp. 267-278 [U. Schlemmer, editor].

van Vliet, T., van Schaik, F. \& van den Berg, H. (1992). [Beta-carotene metabolism: the enzymatic cleavage to retinal.] Voeding 53, 186-190.

Vaziri, N. D., Said, H. M., Hollander, D., Barbari, A., Patel, N., Dang, D. \& Kariger, R. (1985). Impaired intestinal absorption of riboflavin in experimental uremia. Nephron 41, 26-29.

Velázquez, A., Zamudio, S., Báez, A., Murguia-Corral, R., Rangel-Peniche, B. \& Carrasco, A. (1990). Indicators of biotin status: a study of patients on prolonged total parenteral nutrition. European Journal of Clinical Nutrition 44, 11-16.

Verdon, C. P. \& Blumberg, J. B. (1988). Influence of dietary vitamin E on the intermembrane transfer of $\alpha$ tocopherol as mediated by an $\alpha$-tocopherol binding protein. Proceedings of the Society for Experimental Biology and Medicine 189, 52-60.

Vieth, R. (1990). The mechanisms of vitamin D toxicity. Bone and Mineral 11, 267-272.

Villard, L. \& Bates, C. J. (1986). Carotene dioxygenase (EC 1.13.11.21) activity in rat intestine: effects of vitamin A deficiency and of pregnancy. British Journal of Nutrition 56, 115-122.

Vinson, J. A. \& Bose, P. (1988). Comparative bioavailability to humans of ascorbic acid alone or in a citrus extract. American Journal of Clinical Nutrition 48, 601-604.

von Kries, R., Greer, F. R. \& Suttie, J. W. (1993). Assessment of vitamin K status of the newborn infant. Journal of Pediatric Gastroenterology and Nutrition 16, 231-238.

Wagner, C. (1985). Folate-binding proteins. Nutrition Reviews 43, $293-299$.

Wang, X-D., Tang, G-W., Fox, J. G., Krinsky, N. I. \& Russell, R. M. (1991). Enzymatic conversion of $\beta$-carotene into $\beta$-apo-carotenals and retinoids by human, monkey, ferret, and rat tissues. Archives of Biochemistry and Biophysics 285, 8-16.

Warkany, J. (1975). Riboflavin deficiency and congenital malformations. In Riboflavin, pp. 279-302 [R. S. Rivlin, editor]. New York: Plenum Press.

Webb, A. R., Kline, L. \& Holick, M. F. (1988). Influence of season and latitude on the cutaneous synthesis of vitamin $\mathrm{D}_{3}$ : exposure to winter sunlight in Boston and Edmonton will not promote vitamin $\mathrm{D}_{3}$ synthesis in human skin. Journal of Clinical Endocrinology and Metabolism 67, 373-378.

Weber, F. (1981). Absorption mechanism for fat-soluble vitamins and the effect of other food constituents. In Nutrition in Health and Disease and International Development; Proceedings of the XII International Congress of Nutrition, pp. 119-135. New York: Liss.

White, H. B. \& Merrill, A. H. (1988). Riboflavin-binding proteins. Annual Review of Nutrition 8, $279-299$.

Whyte, M. P., Haddad, J. G., Walters, D. D. \& Stamp, T. C. B. (1979). Vitamin D bioavailability: serum $25-$ hydroxyvitamin $\mathrm{D}$ levels in man after oral, subcutaneous, intramuscular, and intravenous vitamin D administration. Journal of Clinical Endocrinology and Metabolism 48, 906-911.

Wolf, B., Grier, R. E., Allen, R. J., Goodman, S. I. \& Kien, C. L. (1983). Biotinidase deficiency: the enzymatic defect in late-onset multiple carboxylase deficiency. Clinica Chimica Acta 131, 273-281.

Wolf, H. (1971). Hormonal alteration of efficiency of conversion of tryptophan to urinary metabolites of niacin in man. American Journal of Clinical Nutrition 24, 792-799.

Wood, H. G. \& Barden, R. E. (1977). Biotin enzymes. Annual Review of Biochemistry 46, $385-413$.

Wu Leung, W. T., Busson, F. \& Jardin, C. (1968). Food Composition Table for Use in Africa. Bethesda, MD: US Department of Health, Education and Welfare, and Rome: FAO.

Yang, Y-M., Simon, N., Maertens, P., Brigham, S. \& Liu, P. (1989). Maternal-fetal transport of vitamin K and $_{1}$ its effects on coagulation in premature infants. Journal of Pediatrics 115, 1009-1013.

Yung, S., Mayersohn, M. \& Robinson, J. B. (1982). Ascorbic acid absorption in humans: a comparison among several dosage forms. Journal of Pharmaceutical Science 71, 282-285. 